\title{
From Land to Water: the Origin of Whales, Dolphins, and Porpoises
}

\author{
J. G. M. Thewissen - Lisa Noelle Cooper • \\ John C. George $\cdot$ Sunil Bajpai
}

Published online: 16 April 2009

(C) The Author(s) 2009. This article is published with open access at Springerlink.com

\begin{abstract}
Cetaceans (whales, dolphins, and porpoises) are an order of mammals that originated about 50 million years ago in the Eocene epoch. Even though all modern cetaceans are obligate aquatic mammals, early cetaceans were amphibious, and their ancestors were terrestrial artiodactyls, similar to small deer. The transition from land to water is documented by a series of intermediate fossils, many of which are known from India and Pakistan. We review raoellid artiodactyls, as well as the earliest families of cetaceans: pakicetids, ambulocetids, remingtonocetids, protocetids, and basilosaurids. We focus on the evolution of cetacean organ systems, as these document the transition from land to water in detail.
\end{abstract}

Keywords Dolphins · Whales · Porpoises · Evolution · Cetacea $\cdot$ Mammals

J. G. M. Thewissen $(\bowtie)$

Department of Anatomy and Neurobiology,

Northeastern Ohio Universities College of Medicine,

Rootstown, OH 44272, USA

e-mail: thewisse@neoucom.edu

L. N. Cooper

Department of Anatomy and Neurobiology,

Northeastern Ohio Universities College of Medicine,

Rootstown, OH 44272, USA

L. N. Cooper

School of Biomedical Sciences, Kent State University,

Kent, OH 44242, USA

J. C. George

Department of Wildlife Management, North Slope Borough,

Box 69, Barrow, AK 99723, USA

S. Bajpai

Department of Earth Sciences, Indian Institute of Technology,

Roorkee 247667 Uttarakhand, India

\section{Introduction}

Whales, dolphins, and porpoises together constitute the Cetacea (English: cetaceans). All modern Cetacea live in water and cannot survive out of the water. In spite of this, cetaceans are mammals. Like other mammals and unlike other vertebrates, they nurse their young; they have three ear bones that are involved in sound transmission (hammer, anvil, and stirrup), and their lower jaws consist of a single bone (the dentary).

Cetacea includes one of the largest species of animal ever, the blue whale ( $27 \mathrm{~m}$ in length, 136,000 kg) but also has some very small modern representatives, e.g., the vaquita $(1.4 \mathrm{~m}$ in length, $42 \mathrm{~kg})$. In spite of the variation in body size, all modern Cetacea are relatively similar in shape: they have a horizontal tail fluke used in swimming; their forelimbs are flippers; there are no external hind limbs; their neck is short, and their body is streamlined.

Cetaceans originated from land mammals (Thewissen and Williams 2002; Fordyce and Muizon 2001). Many features that are common in land mammals have changed in the evolutionary process that led to cetaceans. The presence of hair or fur, for instance, is characteristic of mammals. However, all modern cetaceans lack a hair coat, presumably an adaptation to reduce friction and improve locomotion. In spite of this, some species retain a few hairs on their face and in others the fetus has whiskers (Fig. 1). These are clear signs of their mammalian heritage.

Other features are even more impressive indicators of the land ancestry of cetaceans. Cetaceans have lungs and come to the surface to breathe air, like other mammals and unlike fish. And even though modern cetaceans have bodies fully adapted for life in water, traces of their land ancestry are still present in cetacean embryos: modern cetaceans lack hind limbs, but their embryos still have the beginnings of 


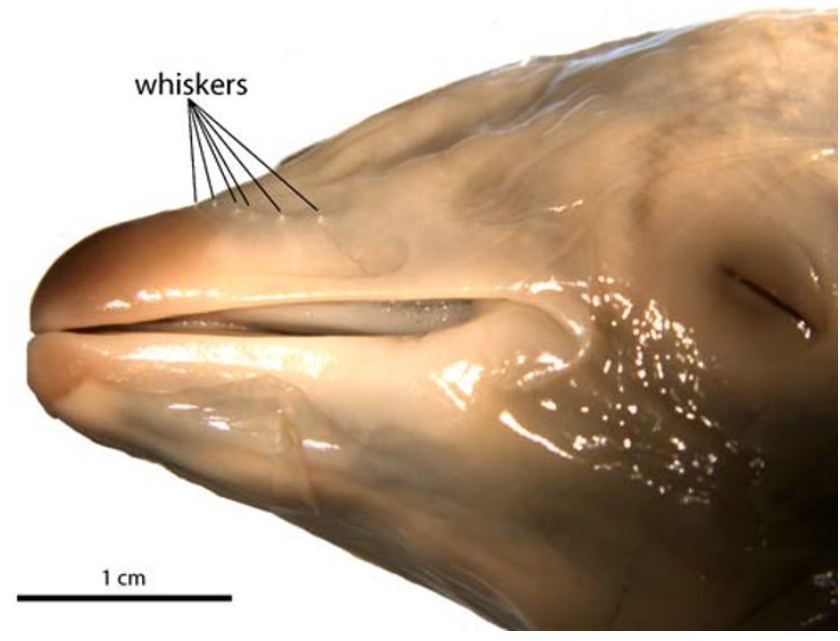

Fig. 1 Fetus of the pantropical dolphin (LACM 94389, Stenella attenuata) with whiskers along the rostrum

hind limbs. Figure 2 shows four embryos arranged from young to old. In the earlier embryos, the hind limbs are present, but then they disappear as embryonic development continues. A disruption of the normal sequence of expression of genes that make these organs is responsible for this (Thewissen et al. 2006).

Cetaceans are unrelated to other marine mammals, the sirenians (manatees and dugongs) and the pinnipeds (seals, sea lions, walruses). Sirenians are most closely related to elephants, and pinnipeds are related to land carnivores (e.g., dogs and bears). In some regards, all cetaceans, sirenians, and pinnipeds are similar; they are all adapted to life in water. For instance, they all have streamlined bodies, short limbs, and fin-shaped hands and feet. In other regards, these three groups are dissimilar. For instance, cetaceans and sirenians lack (nearly all) body hair, whereas pinnipeds have dense fur. On the other hand, whereas the main propulsive organ of cetaceans and sirenians is the tail, sea lions swim with their forelimbs, and seals with their hind limbs.
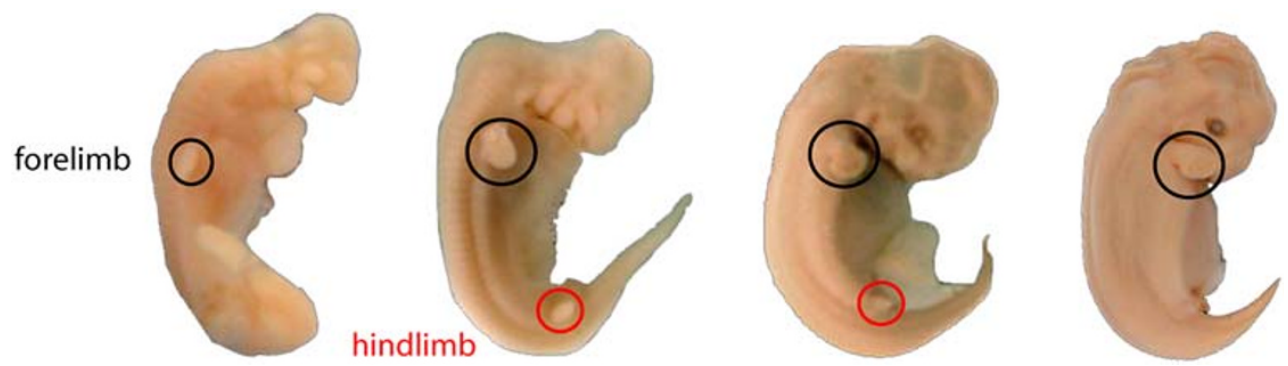

Fig. 2 Embryos of the pantropical spotted dolphin (Stenella attenuata) covering approximately weeks 4 to 9 of embryonic development. The first embryo shows forelimbs but not hind limbs (in most mammals forelimbs develop before hind limbs). In the second embryo is $6 \mathrm{~mm}$, the last one $17.5 \mathrm{~mm}$ in length
Even in Darwin's time, it was known that cetaceans had land ancestors, but fossils that recorded the transition from land to water were not known: all fossil whales bore great similarity to modern whales. This changed in the early 1990s, when paleontologists unearthed the first of a series of fossil cetaceans, mostly in India and Pakistan, documenting the transition from land to water in detail in the Eocene Period (which lasted from approximately 54 to 34 million years ago). Now, cetacean origin is one of the best known examples of macroevolution documented in the fossil record.

\section{Phylogeny: What Cetaceans Are Related To}

Almost as soon as scientists realized that cetaceans had land ancestors, they tried to identify what the closest relatives of cetaceans were. Cetaceans are so different from land mammals that it was difficult to find significant similarities in the anatomy between cetaceans and land mammals. Molecular biology came to the rescue, identifying genetic similarities between cetaceans and artiodactyls (English: even-toed ungulates) that were not present in other mammals. Modern representatives of artiodactyls include pigs, hippos, camels, deer, sheep, cattle, and giraffe, and, of these, hippos are thought to be the closest living relatives of cetaceans (Nikaido et al. 1999; Gatesy and O'Leary 2001).

However, the oldest whale fossils known are approximately 50 million years old, and it is unlikely that the closest relatives of whales are still living. Therefore, it was up to paleontologists to find the artiodactyl that is most closely related to whales among the extinct diversity of even-toed ungulates. This happened in 2007, when skeletons for raoellids were found in the Himalayas that were shown to be the closest relatives to whales (Thewissen et al. 2007).

The study of how organisms are related to each other is called phylogenetic inference, and hypotheses regarding phylogeny are indicated by a cladogram, a branching diagram that links more-and-more closely related groups

embryo, hind limbs have started to form, but their development ceases and they slowly disappear as the embryo grows (third and fourth embryos). These embryos are not drawn to scale. The first 
as closer-and-closer branches. Figure 3 is such a diagram for early cetaceans. The branching of the cetacean groups on this cladogram is consistent with most recent work (Thewissen et al. 2007; Geisler and Uhen 2003; Geisler et al. 2007).

Here, we will present an overview of the most important players in the origin of cetaceans. We will discuss them, starting with raoellids and continuing with archaeocetes, the archaic whales that lived in the Eocene, approximately between 55 and 37 million years ago. We will discuss these following the order of the cladogram. Cetacean evolution continued after that with the two suborders of whales that have modern representatives, Odontoceti (toothed whales, which includes porpoises and dolphins) and Mysticeti (baleen whales), but their evolution is not discussed here. There are several recent reviews of the evolution of odontocetes and mysticetes (Fordyce and Muizon 2001; Bianucci and Landini 2007).

\section{Raoellidae: the Closest Relatives of Cetaceans}

Raoellidae is one of the families of artiodactyls. It contains a small group of species, most of which are only known from teeth and jaws (Thewissen et al. 2001, 2007). Skulls and skeletons are known for a single raoellid: Indohyus (Thewissen et al. 2007). Raoellids are only known from Pakistan and western India and are restricted to the lower and middle Eocene, approximately between 55 and 45 million years ago.

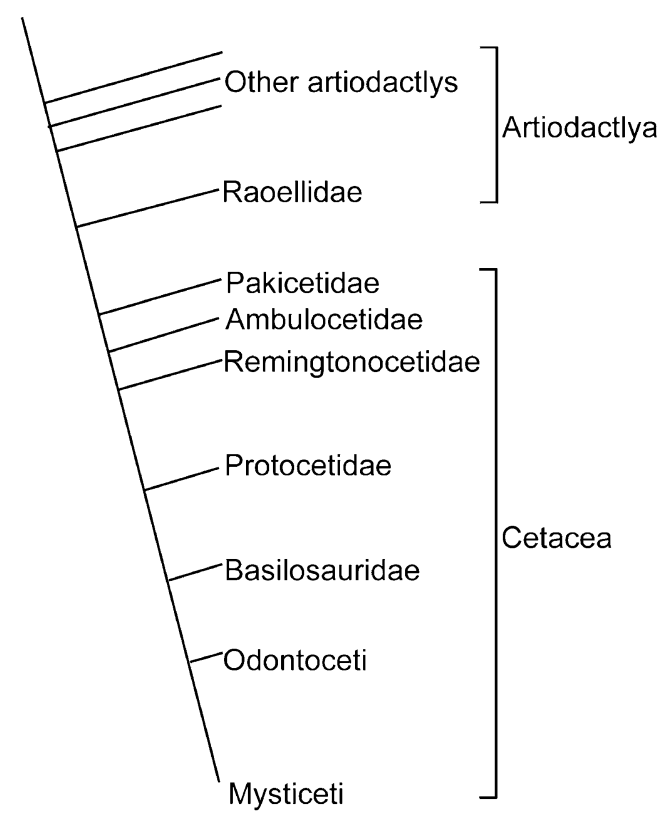

Fig. 3 Diagram showing the relationships among cetaceans and their land relatives. Such a diagram is called a cladogram. Taxa that have more branches of the diagram in common are more closely related

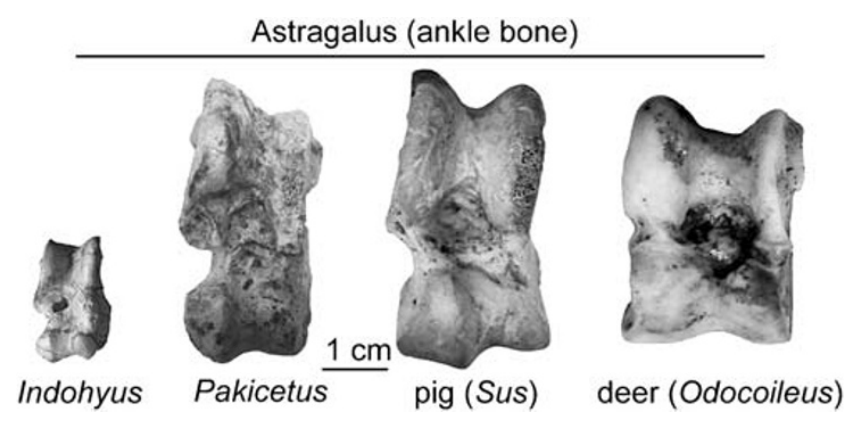

Fig. 4 Astragali (bone of the ankle) of the raoellid Indohyus (RR 224), the pakicetid Pakicetus (H-GSP 98148), a modern pig (3/84), and a modern deer (2/93). This shape of the astragalus, with a proximal trochlea (hinge joint) as well as distal trochlea, only occurs in even-toed ungulates (artiodactyls)

Indohyus was an animal similar in size to a cat but quite different from a cat in shape. It had a long snout and a long tail and long slender limbs. At the end of each limb, there were four or five toes that ended in hoof, similar to that of a deer. Indohyus pertains to the Artiodactyla, which is indicated best by the shape of one of the bones in the ankle. In all mammals, this bone, the astragalus or talus (Fig. 4), has a hinge joint, called a trochlea, where it articulates with the tibia (shin bone). In raoellids and other artiodactyls (and in extinct cetaceans), the astragalus has a second trochlea, which is located on the opposite end of the first trochlea, and this second trochlea articulates with the remaining bones of the ankle. This creates greater mobility in the foot in the anteroposterior direction.

The bones of Indohyus were found high in the Himalaya mountains near the border between Pakistan and India. The rocks in which these fossils are preserved indicate that the bones were buried in a freshwater stream. Many skeletons of Indohyus were washed together, and the bones are jumbled. Such a locality is called a bone bed, and it is not possible to determine which skull went with which other bones. As a result, the skeleton of Indohyus shown in Fig. 5 consists of bones of a number of different individuals.

Several skulls were discovered for Indohyus (Fig. 6) and these are important in determining how it is related to other mammals. The phylogeny among fossil animals can be determined by coding their morphology and having a computer program determine the greatest similarities in significant characters. Such an analysis results in a cladogram, and our study (Thewissen et al. 2007) showed that Indohyus was the closest relative to cetaceans (Fig. 3). One feature that is a strong indicator of this relationship is the shape of one of the bones of the ear. The middle ear is an air-filled cavity in the skull and is involved in sound transmission. In most mammals, its walls are made of a bone called the ectotympanic, as is the case in artiodactyls and cetaceans. The ectotympanic of artiodactyls roughly has the shape of half a walnut shell, enclosing the air-filled 
Fig. 5 The skeleton of the raoellid artiodactyl Indohyus. Bones shown here are derived from several individuals and were found scrambled with many other bones near the border area between Pakistan and India by geologist A. Ranga Rao (C J.G.M. Thewissen)

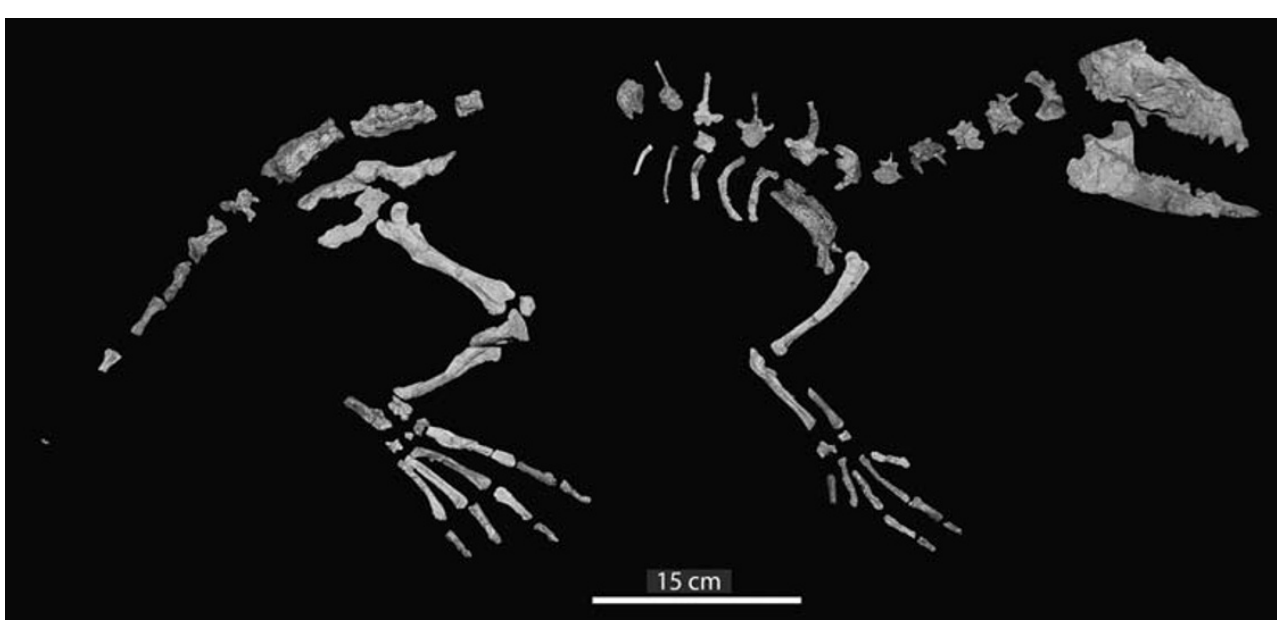

middle ear cavity. The thickness of the wall is more or less constant all around the ear in most mammals, but this is not the case in cetaceans, where the internal wall is much thicker than the external wall. This thickened wall is called the involucrum and is present in all cetaceans, fossil and recent. The involucrum is not present in other mammals, except for one: Indohyus (Fig. 7). The ectotympanic of Indohyus has a thickened internal lip, a powerful indicator that Indohyus is closely related to cetaceans. In the past, the presence of an ectotympanic with an involucrum was the main character supporting the inclusion of a species in Cetacea, and it is therefore sometimes advocated that Indohyus (or Raoellidae) be included in Cetacea. While we believe that there are some benefits to this view, we lean against it. In our view, classifications of animals above the species level are mostly vehicles for communication between scientists, and communication is greatly hampered by classifications that are not stable: changing the content of Cetacea by including Indohyus leads to instability of Cetacea. The phylogenetic relations among groups are best expressed by a cladogram, and classifications cannot accurately reflect phylogenetic relationships anyway (because an ancestor species would have to include all its descendant species). Raoellidae has been a family of artiodactyls for more than 20 years; the recent finding by one group of authors (Thewissen et al. 2007) that they are related to cetaceans is insufficient reason to change that.

Another surprising feature in the skeleton of Indohyus was found in the bones of its extremities. The larger bones of the extremities of mammals are usually hollow, and the cavity in them is filled with bone marrow. Usually, on cross section (Fig. 8), the marrow cavity of the femur (the

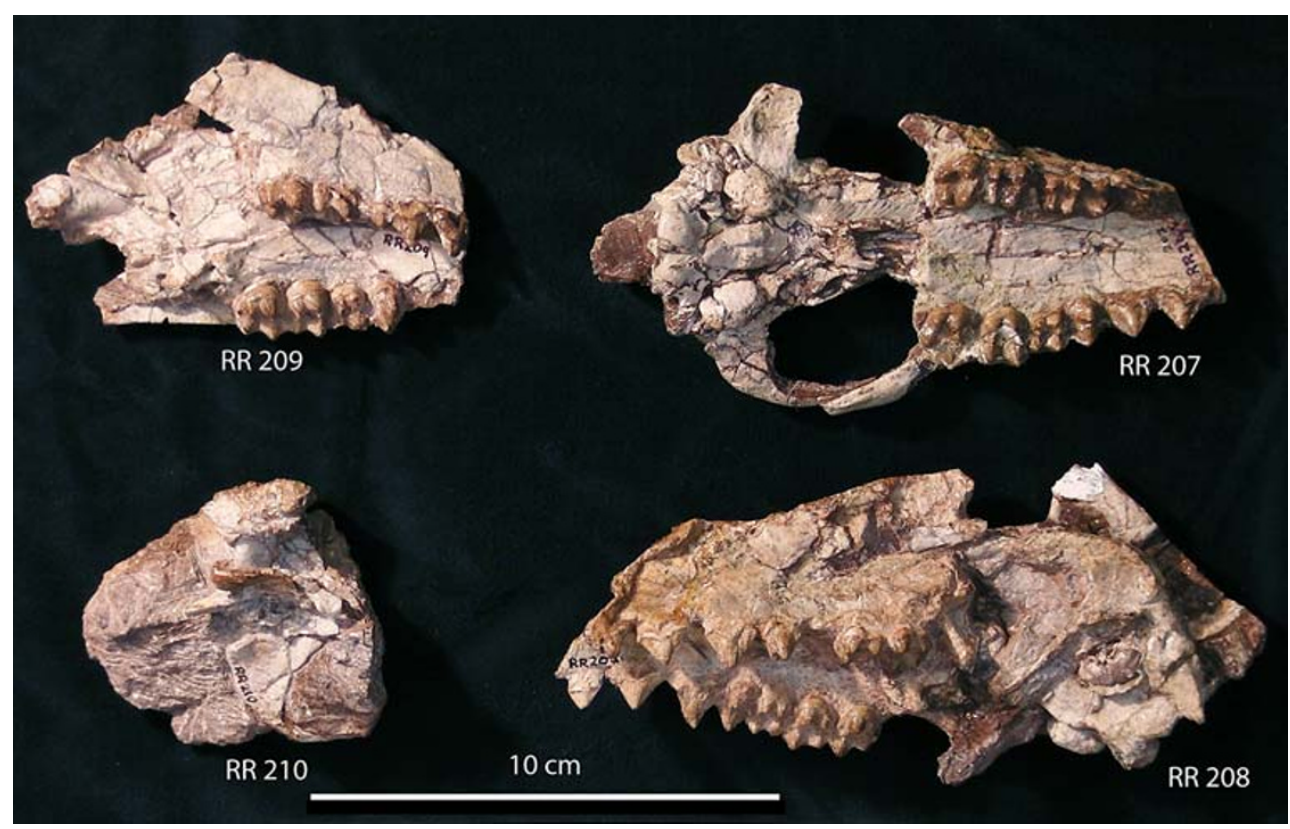

Fig. 6 Skull and skull fragments of four individuals of Indohyus. Numbers are used to refer to individual specimens. RR 209 has the back of the palate with the region for the eyes; RR 210 is the braincase; RR 207 and 208 are a nearly complete skull, just lacking the region of the incisors 


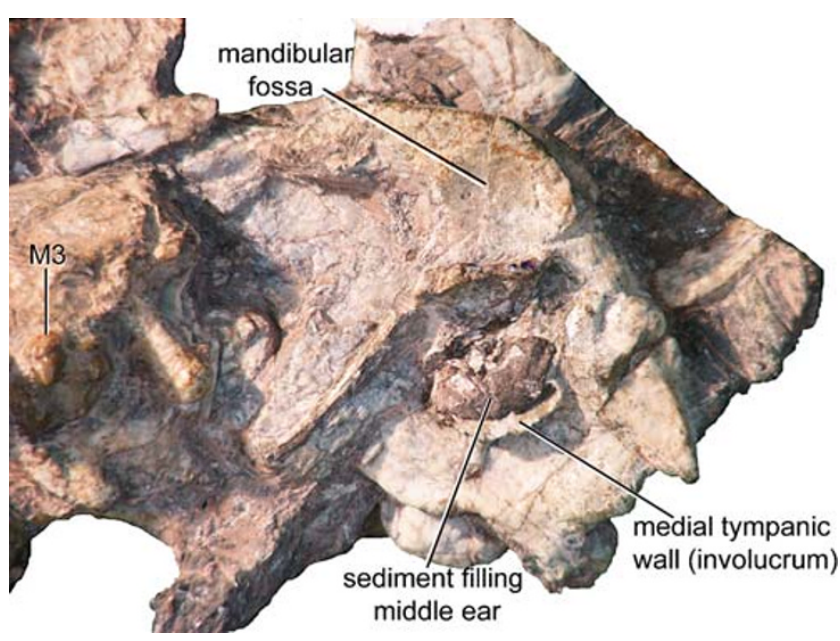

Fig. 7 Detail of the ear region of a skull in Fig. 6 (RR 208). M3 is the last molar in the upper jaw, and the mandibular fossa is the jaw joint. The middle ear is filled with air in life and has a bony wall, similar in shape to a nutshell. The bony wall is broken in this specimen, showing the thickness of the wall (medial tympanic wall). It also exposes the inside of the middle ear, which is filled with sediment here

thighbone) makes up more than $60 \%$ of the total thickness of the bone, and the bony walls, called cortex, are thin. However, the bone of Indohyus is much thicker and the marrow cavity, consequently, smaller, only $42 \%$ of the bone (Thewissen et al. 2007). This feature makes the bones heavy, and heavy bones make running on land more difficult. Such heavy bones are called osteosclerotic and are common in aquatic mammals that are waders or bottom walkers but not swimmers. In Hippopotamus, for instance, the marrow cavity makes up $55 \%$ of the total thickness of the femur. This helps the animal walk on the bottom of rivers, where the extra bone mass serves as ballast. In early whales (Pakicetus, Ambulocetus, see below), osteosclerosis also occurs, and this ratio is $57 \%$.

Further evidence of the aquatic habitat for Indohyus comes from the chemical composition of its teeth. Teeth consist mostly of calcium phosphate. Oxygen in the molecules that make up the teeth comes from the drinking water and food that the animal ingests. Two isotopes, forms of elements that are chemically identical but have heavier atoms because of excess neutrons in the nucleus, are common in nature: Oxygen-16 and Oxygen-18 (where the number reflects the mass of the atom). Oxygen-16 is by far the more common isotope (over $99 \%$ in nature), but the ratio between Oxygen-16 and Oxygen-18 varies in different environments, and animals living in water have a different ratio compared to animals living on land (Roe et al. 1998; Clementz et al. 2006). A stable isotope study of the teeth of Indohyus also suggested that it lived in water (Thewissen et al. 2007).

These results suggest that Indohyus was aquatic and thus that cetaceans originated from aquatic ancestors. It may seem odd that a 47-million-year-old artiodactyl that looks like a tiny deer is aquatic, but this behavior is reminiscent of one species of modern artiodactyl. The African mouse deer (Hyemoschus aquaticus) lives on the forest floor of central Africa, feeding mostly on fruits and flowers. It always stays near water, and when in danger from a predator, Hyemoschus jumps in the water and scurries to safety fully submerged. A remarkable video of this behavior is posted on www.youtube.com and is called Eagle versus Water Chevrotain (chevrotain is the French name for African mouse deer).

Hyemoschus is not osteosclerotic and spends relatively little time in the water. Given its morphology, it appears that Indohyus is more aquatic than Hyemoschus and may have spent much of its life in water. It is possible that it fed on water plants, but it is also possible that it came on land to feed on land plants, in a way similar to modern hippos.

With aquatic origins for cetaceans now being known to occur within the artiodactyls, the search is on for the discovery of the terrestrial relatives of raoellids. It is possible that these relatives are also closely related to hippopotamids, which would make molecular and morphological phylogenies consistent.

\section{Pakicetidae: the First Cetaceans}

Pakicetids are the most archaic cetaceans known. Although the first fossils for this group were discovered before World

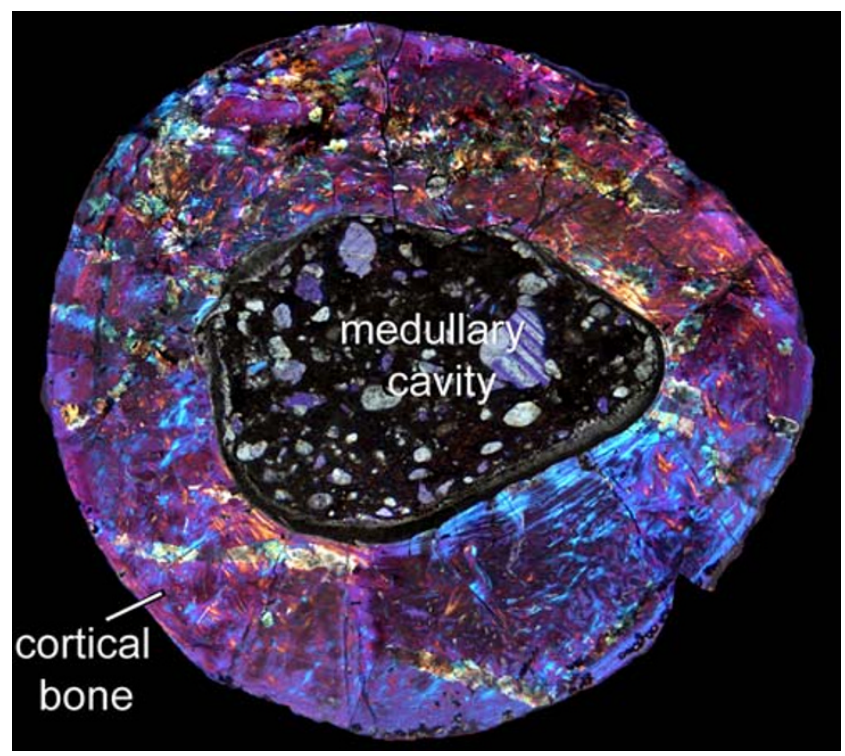

Fig. 8 Cross section of the femur (thighbone) of Indohyus (RR 42). The purple-blue color is fossilized bone in this image taken with a polarized light microscope with a gypsum filter. The marrow cavity is filled with sediment (gray in this image; http://www.neoucom.edu/ audience/about/departments/anatomy/AnatFaculty/media, (C) J.G.M. Thewissen) 
Fig. 9 Composite skeletons of the pakicetid cetaceans Pakicetus (left) and Ichthyolestes (right). (Image from Thewissen et al. (2001), (C) Nature)

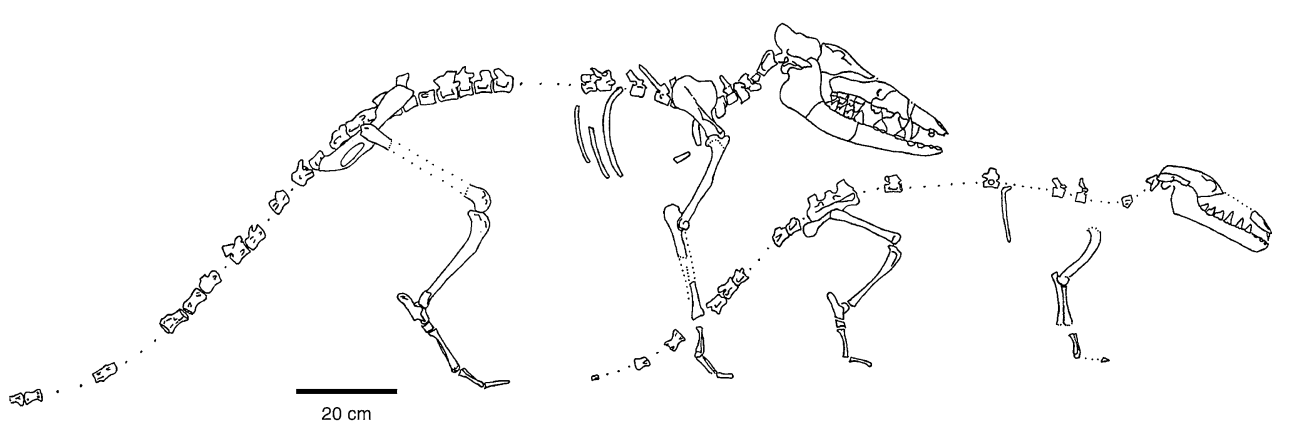

War II, these were so fragmentary that they were not recognized as cetaceans. It was not until 2001 that skeletons of these whales were discovered (Thewissen et al. 2001; Nummela et al. 2006; Madar 2007; Fig. 9). Pakicetids are only known from a few sites in northern Pakistan and Western India, and these are approximately 50 million years old (middle Eocene). The largest collection of pakicetid fossils is known from the Kala Chitta Hills of Northern Pakistan, from a site called H-GSP Locality 62. This locality is a bone bed, scattered with fossils from many different animals (Fig. 10). There are three genera of pakicetid whales, Ichthyolestes, Pakicetus, and Nalacetus, and skulls for all of these have been found at Locality 62 (Fig. 11). The sheer volume of bones of unrelated animals at one locality makes it impossible to identify all the bones of one individual. Therefore, skeletons of pakicetids are composites based on bones from a number of different individuals, identified based on their size, their similarity to other primitive whales, the chemical composition of the bones, and the relative abundance at their locality. The sediments at Locality 62 can inform us about the environment in which pakicetid whales lived (Aslan and Thewissen 1997) and in which more than $60 \%$ of the fossils are pakicetids (Thewissen et al. 2001). It was a shallow stream, and the climate was hot and dry. Rains came only a few times per year, but they were torrential. The stream bed broke up into shallow pools most of the year, and water was only flowing during the rainy periods.

Externally, pakicetids look nothing like a modern cetacean. They are more similar to a wolf with a long nose and tail (Thewissen et al. 2001; www.neoucom.edu/ DEPTS/ANAT/Thewissen/whale_origins/whales/Pakicetid. html). However, the details of the pakicetid skeleton tell a different story; this was not an ordinary land predator. The skulls show that the orbits (the sockets of the eyes) of these cetaceans were located close together on top of the skull, as is common in aquatic animals that live in water but look at emerged objects. Just like Indohyus, limb bones of pakicetids are osteosclerotic (Madar 2007), also suggestive of aquatic habitat, an interpretation consistent with stable isotope evidence (Roe et al. 1998; Clementz et al. 2006).

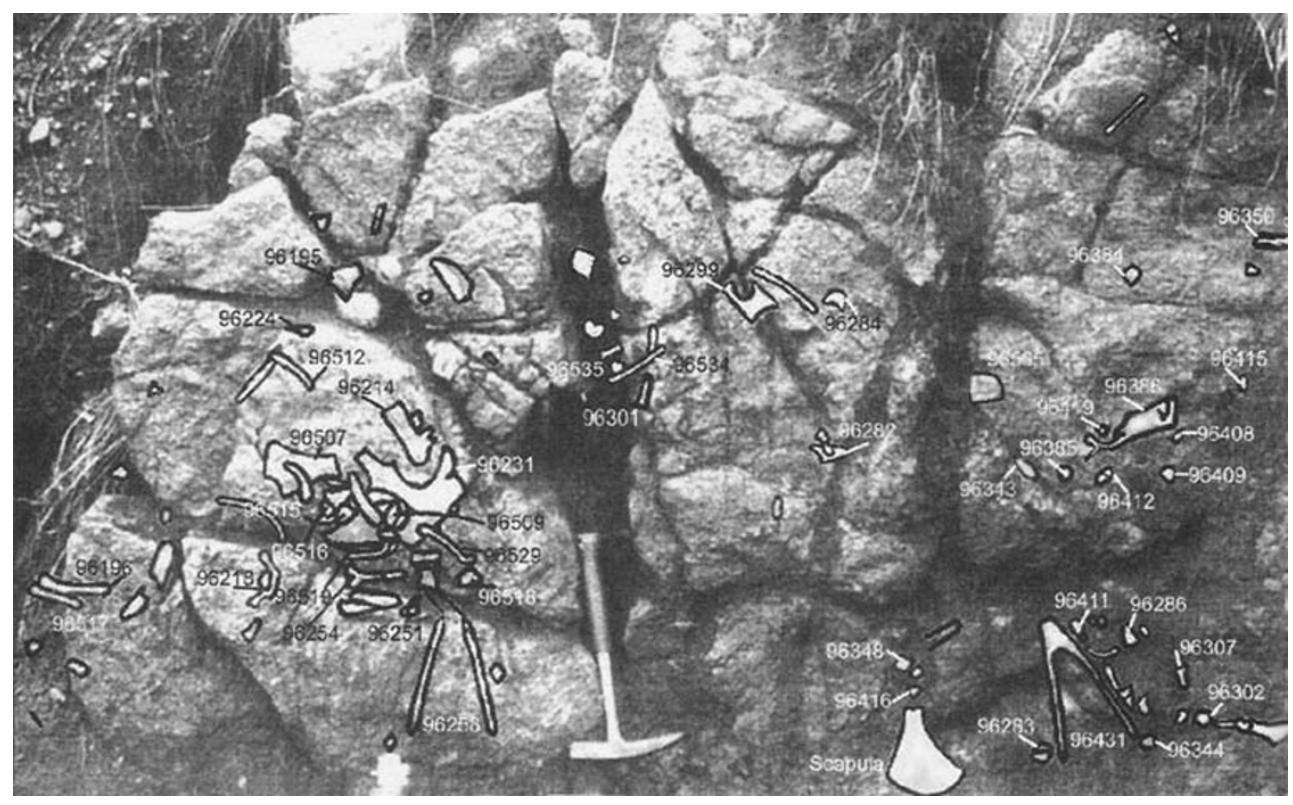

Fig. 10 Fossiliferous area of H-GSP Locality 62, the richest locality for pakicetid cetaceans. Outlines indicate where specific fossils were buried, and the hammer provides a scale (image from Thewissen and Williams (2002), (C) Annual Reviews) 
Fig. 11 Four skulls of pakicetid cetaceans. The snout and teeth are missing in all four specimens, but the orbits (eye sockets) are preserved. This suggests the snout is only weakly attached to the skull

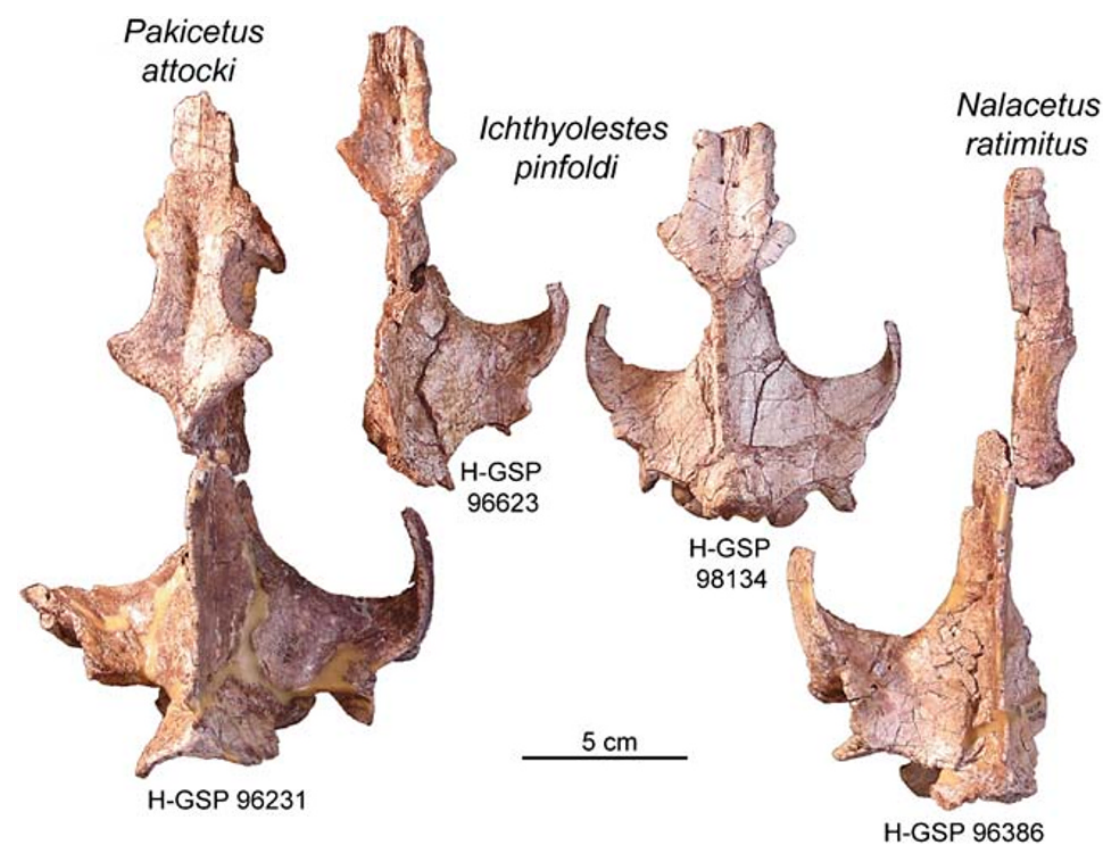

Pakicetids are related to artiodactyls, as was shown by the cladistic analysis (Gatesy and O'Leary 2001; Geisler et al. 2007; Thewissen et al. 2001), and as is beautifully indicated by the presence of an astragalus with two trochleas (Fig. 4). Just like raoellids and all cetaceans, pakicetids have an involucrum, the thickened inner lip on the tympanic bone (Fig. 12).

About 50 million years ago, during the evolution from (raoellid) artiodactyls to (pakicetid) cetaceans, a remarkable transformation took place. Both raoellids and pakicetids had aquatic adaptations, wading and walking in freshwater streams. However, they lived in very different ways. Pakicetids have teeth with cusps (the elevated bumps on a tooth) that are high, separated by deep valleys from other cusps (Fig. 13). Pakicetids also have tooth wear that is highly unusual, with large polished areas on their enamel, caused by tooth-to-tooth contact. This wear pattern has been correlated to fish eating (O'Leary and Uhen 1999). In addition, the part of pakicetid skulls behind the eyes (orbits) and the joints for the lower jaw (mandibular fossa) is very narrow (Fig. 14). This affects the attachment of the masticatory muscles but also the path of the nerves going to eyes and nose. This implies that pakicetids ate different food and processed it differently from raoellids and that they had different sense organs. Scientists are still trying to understand what exactly these differences mean, but they must have affected function of the animals in a major way. The transition from raoellid to pakicetid and thus from artiodactyl to cetacean was a remarkable event that included the wholesale rebuilding of the skull and its foodprocessing equipment.

Summarizing, pakicetids inherited the aquatic lifestyle from their raoellid ancestors. The position of the eyes, osteosclerosis of the limb bones, sedimentological data, and stable isotope data are consistent, and all suggest that pakicetids were waders in shallow freshwater.

Fig. 12 Ectotympanic bones of Pakicetus and the modern dolphin Lagenorhynchus. This bone surrounds the middle ear cavity like a bowl. In all cetaceans, the medial wall of the ectotympanic is very thick, as indicated by the white line, and is called the involucrum
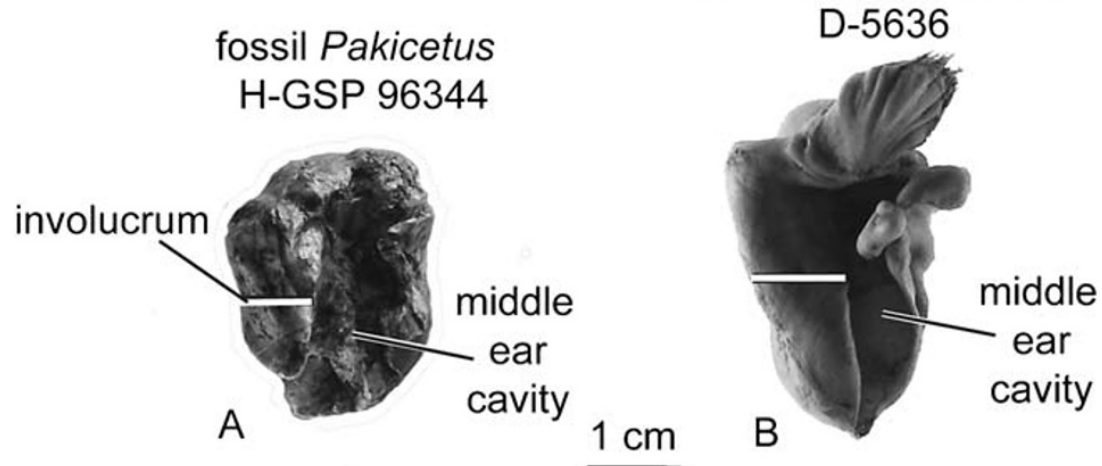
Fig. 13 The teeth of Indohyus (left) are different from the teeth of pakicetids (right) in that Indohyus has upper molar teeth with four cusps. Pakicetid upper molars have three cusps. The wear facets (indicated by patterns of reflected light) may indicate that pakicetids were eating fish

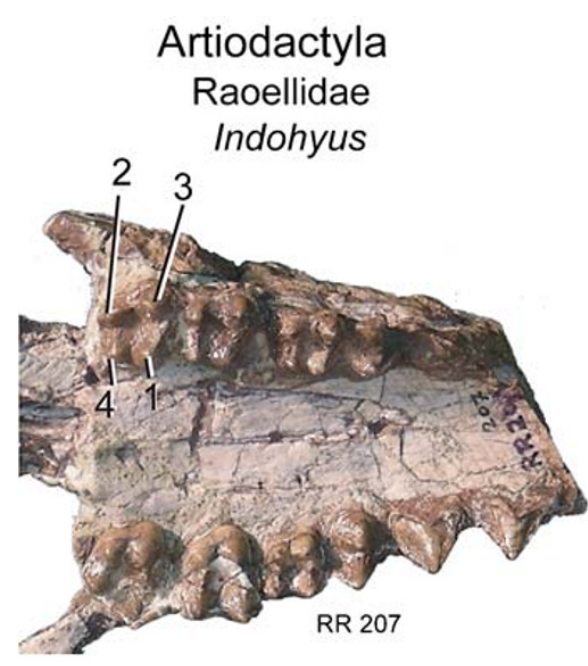

Cetacea Pakicetidae

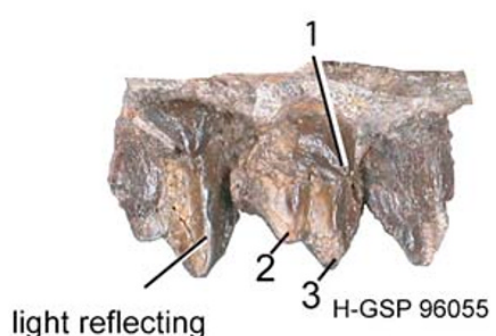
on wear facets

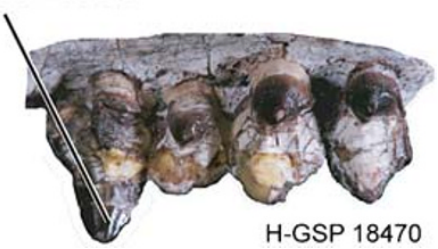

\section{Ambulocetidae: the First Marine Cetaceans}

Fewer than ten fossils of ambulocetids have been discovered, but one of these is a relatively complete skeleton of Ambulocetus natans (Fig. 15), the walking and swimming whale (ambulare is Latin for to walk, cetus is Latin for whale, and natans for swimming; Thewissen et al. 1994, 1996; Madar et al. 2002). The bones of one individual were found together, partly articulated. This skeleton includes the skull and the vertebral column, one forelimb and parts of both hind limbs. Only a few tail vertebrae have been discovered. Fossils of ambulocetids can be classified in

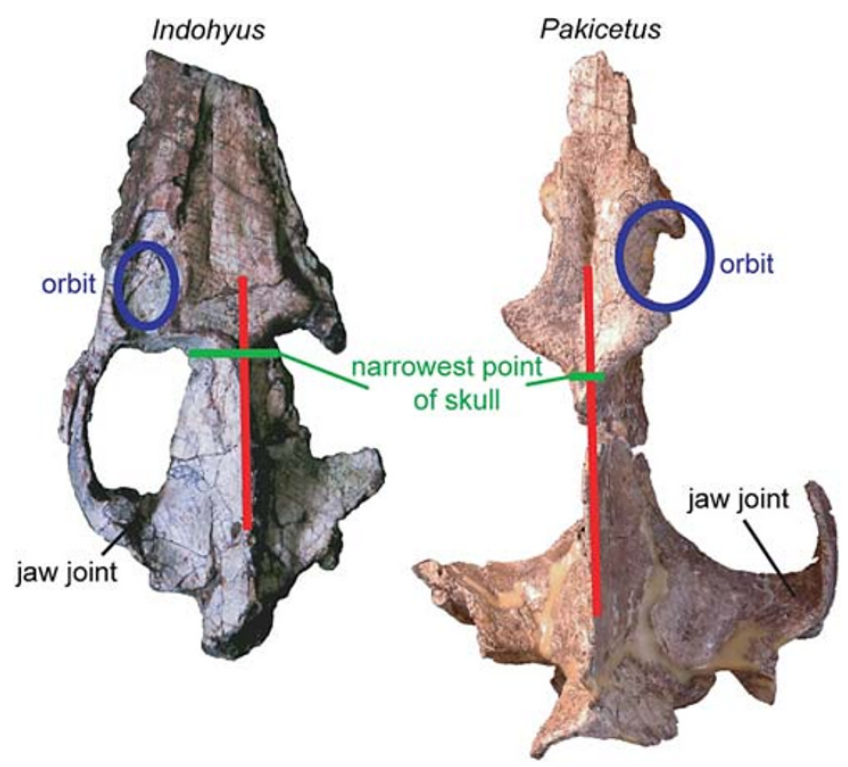

Fig. 14 Differences in skull architecture between Indohyus (RR 207) and Pakicetus (H-GSP 96231). The red line indicates the distance, projected on the midline, between the middle of the orbit (eye) and the mandibular fossa (jaw joint). The green line indicates the minimal width of the skull three genera, and remains of these have been found in Northern Pakistan and northwestern India. Ambulocetid fossils are approximately 49 million years old (middle Eocene).

Ambulocetus is much larger than any pakicetid (Fig. 16), roughly the size of a large male sea lion. This early whale has short and powerful legs, with five fingers in the hand and four toes in the foot. The feet are much larger than the hands. The tail vertebrae are robust, suggesting that the tail was muscular. Just like Pakicetus, ambulocetids had osteosclerotic limb bones (Madar 1998). The marrow cavity of the femur of Ambulocetus makes up 57\% of the cross section of the bone. This suggests that Ambulocetus lived in water and was not a fast-moving predator. Aquatic life for Ambulocetus is consistent with the stable isotope data (Roe et al. 1998). It appears most likely that Ambulocetus was an ambush predator, attacking prey that came close to it but not pursuing it over long distances. In hunting behavior, Ambulocetus may have been similar to a modern crocodile, and, externally, Ambulocetus may have looked like a crocodile (http://www.neoucom.edu/DEPTS/ANAT/ Thewissen/whale_origins/index.html).

The skull of Ambulocetus has a long snout, as evidenced by the long lower jaw (much of the upper jaw is not preserved). In pakicetids, the eyes faced upward, whereas in Ambulocetus, they face toward the sides, although they are still located high on the skull (Nummela et al. 2006). This eye position occurs in aquatic mammals such as hippopotamus.

The limb proportions (relative length of the thighs, feet, and hands, etc.) of the skeleton of Ambulocetus are similar to those of river otters (Thewissen and Fish 1997). River otters swim with their hind limbs and tail, and it is likely that Ambulocetus did the same. Frank Fish (1996) discussed the evolution of different swimming modes in mammals 
Fig. 15 The skeleton of $A$. natans (H-GSP 18507) had a large pelvis that supported the animal as it walked on land, but the tail and hind limbs were used during swimming (http:// www.neoucom.edu/DEPTS/ ANAT/publ.html, (C) J.G.M. Thewissen). The hammer provides a scale

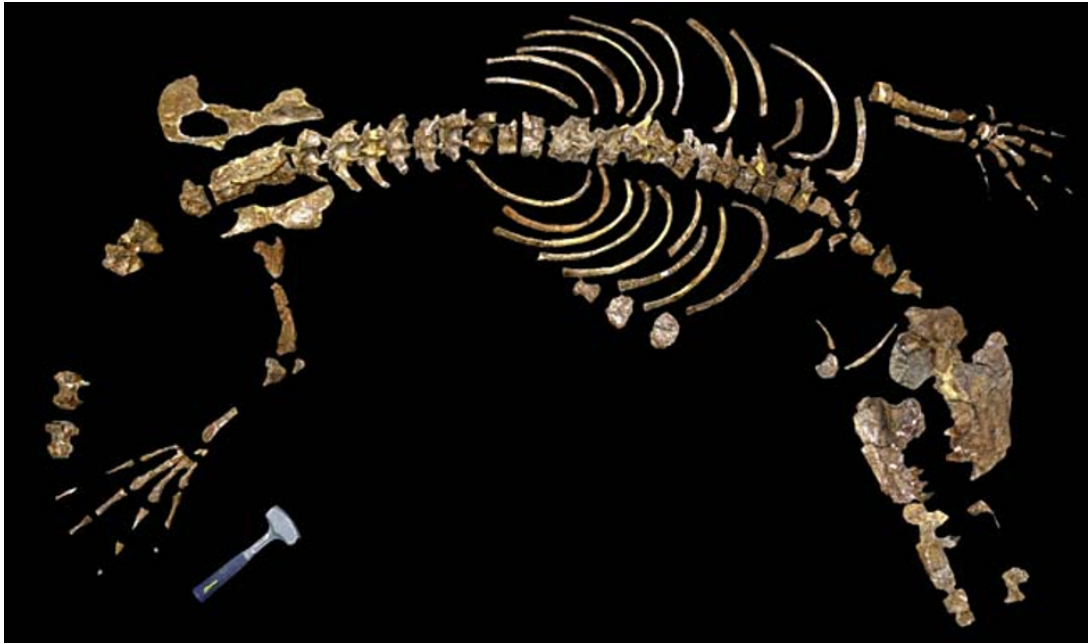

(Fig. 17). Writing before the discovery of Ambulocetus, Fish predicted that the swimming mode of modern cetaceans (moving the fluke through the water in the dorsoventral plane) was preceded by a swimming mode that included dorsoventral sweeps of the feet aided by a long tail, similar to otters. The discovery of Ambulocetus showed that Fish's prediction is probably correct: limbs of $A m b u$ locetus are proportionally similar to modern river otters (Thewissen and Fish 1997).

Ambulocetus fossils have only been found in rocks that were formed in a shallow sea, possibly in a coastal swamp or forest. Stable isotope data indicate that Ambulocetus lived in environments that were partly freshwater, possibly implying that they were near a river mouth (Roe et al. 1998).

\section{Remingtonocetidae: Long-Snouted Cetaceans}

The oldest representatives of the Remingtonocetidae are found at the same fossil localities as Ambulocetus, but the greatest diversity of remingtonocetids is known from younger rocks, between 48 and 41 million years ago in India and Pakistan (Gingerich et al. 1997). In all, there are four or five genera of remingtonocetids, characterized by a long snout, which makes up nearly two thirds of the length of the skull.

Dentally, remingtonocetids are specialized (Thewissen and Bajpai 2001a); their molars have lost the crushing basins of pakicetids and ambulocetids. This suggests that the diet of remingtonocetids is different from that of earlier cetaceans.

In the genus Remingtonocetus, the eyes are very small (Thewissen and Nummela 2008), but the ears are large and set far apart on the skull, a feature that enhances directional hearing. In details of ear anatomy too, remingtonocetids are more specialized than pakicetids and ambulocetids (Nummela et al. 2007). One hearing-related feature is the size of the mandibular foramen, a perforation of the lower jaw behind the teeth. The foramen is enormous, covering nearly the entire depth of the jaw in modern cetaceans and reming-

Fig. 16 The skeletons of

Ambulocetus (top) and

Pakicetus (bottom), (c) J.G.M.

Thewissen

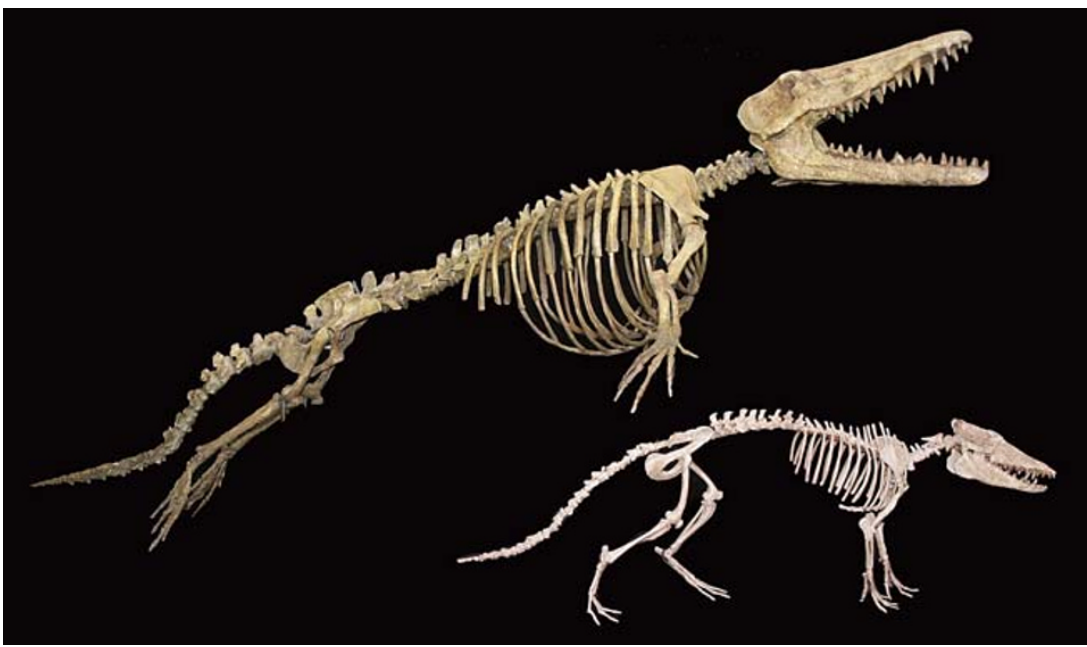




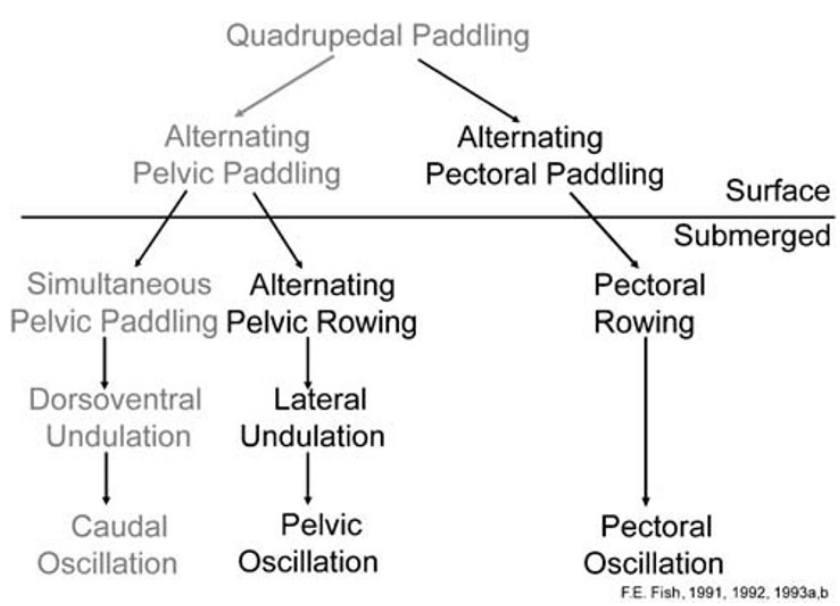

Fig. 17 Model of cetacean locomotor evolution as proposed by Fish (1996). Cetaceans probably followed the gray path on the left. The skeleton of Ambulocetus suggests that it swam by moving the hind limb and tail in dorsal and ventral undulations. Modern cetaceans undulate their tails dorsally and ventrally

tonocetids, unlike pakicetids, where it is smaller (Fig. 18). In all mammals, this foramen carries the nerves and blood vessels to the lower teeth and chin, but this does not account for its size in cetaceans. In modern cetaceans, this foramen carries, in addition to the nerves and blood vessels mentioned, a long pad of fat which connects the lower jaw to the middle ear and transmits underwater sounds. This pad was also present in remingtonocetids, suggesting that underwater sound transmission was effective in remingtonocetids, a clear aquatic adaptation (Nummela et al. 2007, 2004).

Remingtonocetids are also important because they document evolution in another major sense organ. The organ of balance is located in the petrosal, a bone attached to the ectotympanic. A major part of the organ of balance consists of three circular tubes, arranged in three planes that are at right angles to each other (Fig. 19). In general, the diameter of these tubes, the semicircular canals, scales with body size (Spoor and Thewissen 2008), but the canals are extremely reduced in modern cetaceans. The reason for this reduction is not fully understood, but it is possible that the reduction is related to the emergence of an immobile neck (Spoor et al. 2002). In mammals where it has been studied experimentally, a neural reflex, the vestibulocollic reflex, is engaged by stimulation of the semicircular canals and causes the neck muscles to contract and leads to the stabilization of the head, reducing the effect of sudden body movements on the head. Most modern cetaceans have a relatively stiff neck, and it is likely that this reflex, if present at all, cannot stabilize the head because the neck is already relatively immobile. This could then lead to overstimulation of the semicircular canals, especially in acrobatic animals. Reducing the size of the canals would reduce the chances of overstimulation and also limit the sensitivity of the canals. As such, it may give cetaceans the opportunity to be acrobatic. Remingtonocetids and all cetaceans higher on the cladogram have small canals, but pakicetids have large canals. The canals are not preserved in any Ambulocetus specimen.

The morphology of the sense organs suggests that hearing was important for Remingtonocetus but that vision was not. This is consistent with the environmental evidence from the rocks that the fossils are found in. Indian Remingtonocetus probably lived in a muddy bay protected from the ocean by islands or peninsulas. Rivers may have brought sediment into this bay, and the water may not have been transparent.

The postcranial skeleton of remingtonocetids (Bajpai and Thewissen 2000) shows that these whales had short legs but a very long powerful tail. Consistent with Fish's hypothesis regarding the evolution of cetacean locomotion, these cetaceans may have used their tail as the main propulsive organ in the water and only used their limbs for steering, and they were probably fast swimmers, although the semicircular canals indicate that there was limited ability for locomotion on land. Modern giant South American river otters (Pteronura brasiliensis) have a long tail that is flat dorsoventrally and that is swept up and down during swimming. This type of locomotion may be a good model for swimming in Remingtonocetus. Therefore, externally, remingtonocetids may have resembled enormous otters with long snouts (www.neoucom.edu/DEPTS/ANAT/ Thewissen/whale_origins/whales/Remi.html).

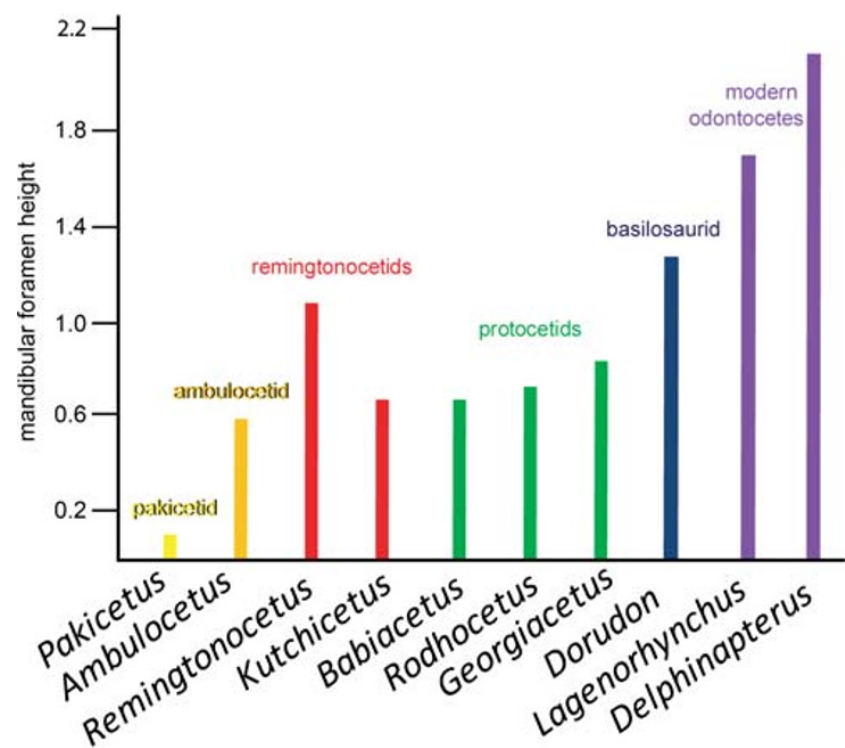

Fig. 18 Relative height of the mandibular foramen (mandibular foramen height divided by height of the mandible at the last tooth) in fossil cetaceans and modern odontocetes 

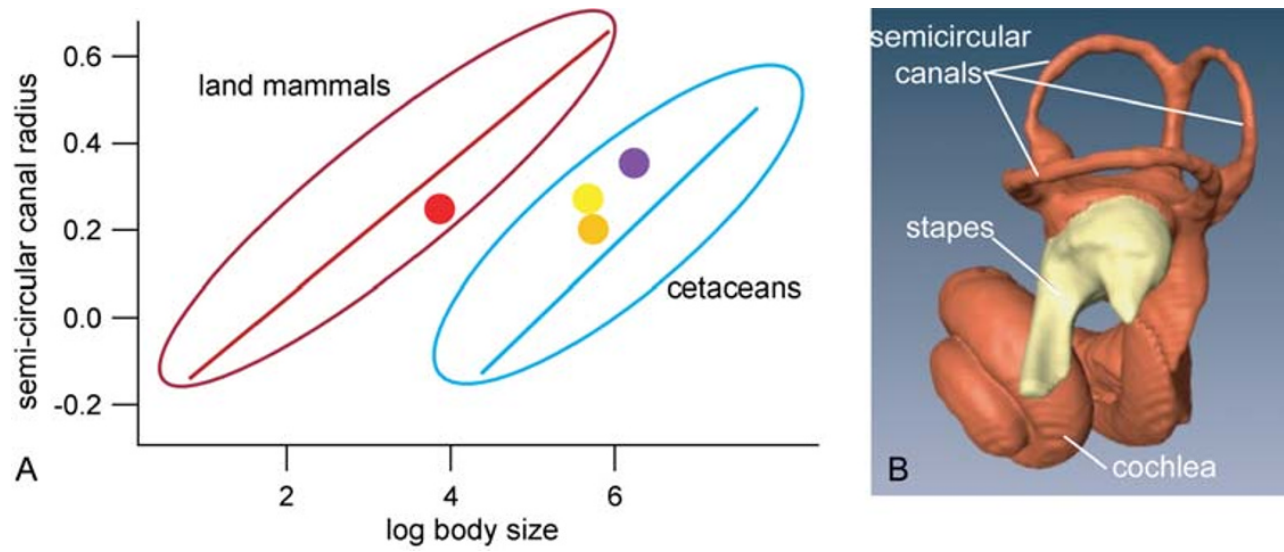

Fig. 19 a Outline ellipses and regression of body size (on $x$-axis, as 10 - $\log$ in grams) against semicircular canal radius (on $y$-axis, as 10$\log$ in $\mathrm{mm}$ ) for modern land mammals (maroon) and modern cetaceans (blue). Fossil cetaceans are the pakicetid Ichthyolestes (red), the remingtonocetid Remingtonocetus (orange), the protocetid Indocetus

\section{Protocetids: the Cetaceans that Conquered the Oceans}

The earliest cetaceans, pakicetids, ambulocetids, and remingtonocetids are only known from India and Pakistan. With the origin of protocetids, cetaceans spread across the globe. Protocetids are known from low latitudes of Asia, Africa, Europe, and North America, and it is likely that they had a worldwide distribution in the middle Eocene between 49 and 40 million years ago (Gingerich et al. 1997; Williams 1998; Geisler et al. 2005).

Protocetids are a diverse group, with approximately 15 genera described. For many of these, no complete skeletons are known, but it appears clear that protocetids were a diverse family, with great variety in such features as snout length and ear morphology. A point of similarity among protocetids is the position and size of the eyes, which differentiates them from earlier cetaceans (Nummela et al. 2006; Gingerich et al. 2001a). The eyes are always large (unlike remingtonocetids), face laterally (unlike pakicetids and some remingtonocetids), and are set far from the midline of the skull under a thick flat skull roof called the (yellow), and the basilosaurid Dorudon (purple). Modified from Spoor et al. (2002). b A reconstruction of inner ear of modern bowhead whale, showing semicircular canals above, broken stapes (yellow), and the cochlea below

supraorbital shield (unlike ambulocetids, pakicetids, and some remingtonocetids). Also unlike earlier cetaceans, the nasal opening is not at the tip of the snout (Thewissen and Bajpai 2001b). Instead it is located further posterior on the snout, foreshadowing the formation of the blowhole of later whales (Fig. 20). The blowhole in modern cetaceans is located between the eyes on the forehead, an adaptation for breathing while remaining submerged.

Variation in the skeleton behind the skull is hard to assess because these bones are only known in a few species, specifically Rodhocetus and Artiocetus from Pakistan (Gingerich et al. 1994, 2001b; Fig. 21), and Georgiacetus from North America (Hulbert et al. 1998; Hulbert 1998). In Artiocetus and Rodhocetus, the limbs are short; the hand had five fingers, and the foot had four toes, and the foot was much larger than the hand, somewhat similar to Ambulocetus. These Pakistani protocetids were certainly able to locomote on land, and it is likely that they used land and water in the way that modern sea lions do: hunting in water but coming ashore for mating, giving birth, and nursing. Land locomotion must have been slow since the
Fig. 20 The earliest cetaceans had nasal bones (gray) and a nasal opening (black) near the tip of the snout. As cetaceans became more aquatic, the nasal bones retracted and the nasal opening migrated to the top of the skull and became the blowhole (modified from Thewissen and Bajpai 2001b)
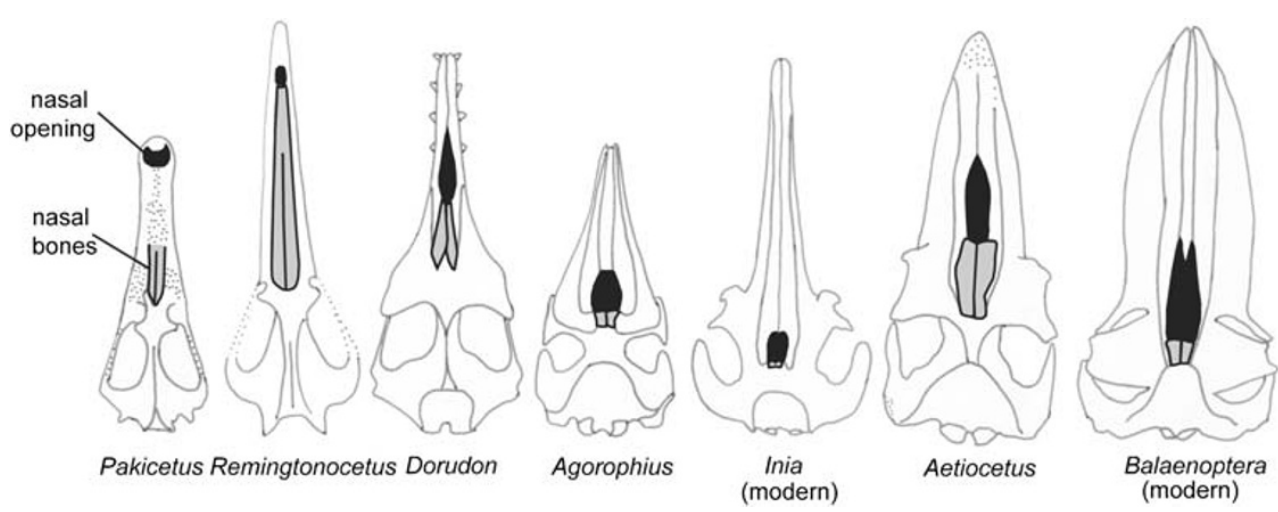


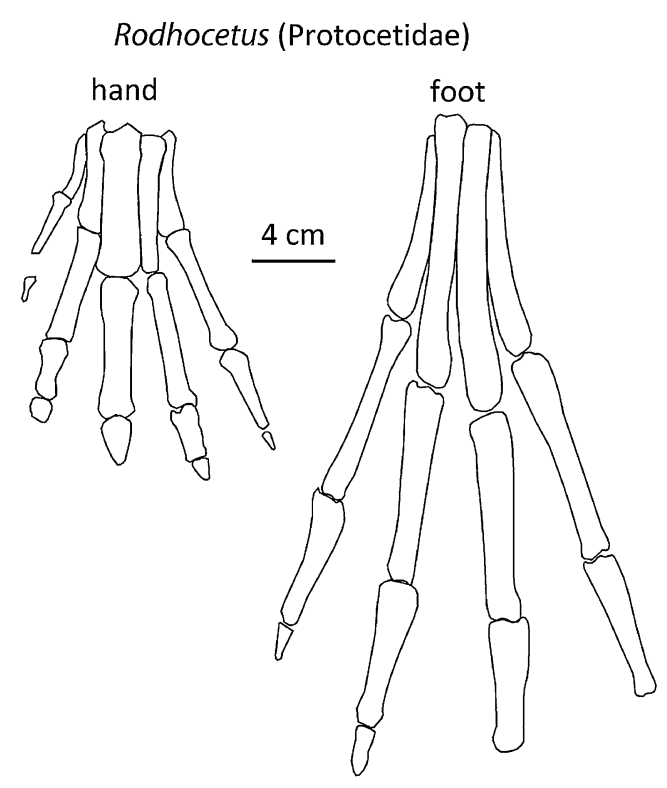

Fig. 21 Hand and foot of the protocetid Rodhocetus (modified from Gingerich et al. 2001b)

semicircular canals were small (Spoor et al. 2002). In Georgiacetus, the only limb element known is the pelvis, and it appears to not have been connected to the vertebral column, suggesting that these limbs could not support the animal's weight. Georgiacetus may have been significantly more aquatic than the other protocetids.

Locomotor abilities in water may also differ between protocetids. While early reports on protocetid skeletons proposed that a fluke was present (Gingerich et al. 1994), it is now generally accepted that protocetids lacked a fluke (Gingerich et al. 2001b; Buchholtz 1998). Swimming may have been a combination of paddling with the hind limbs and dorsoventral undulations of the tail.

Little is known about the diet and feeding morphology of protocetid cetaceans, but, there too, variation appears to be common. Protocetids such as Babiacetus have heavy jaws (Fig. 23) with large teeth, suggestive of a diet that includes hard elements (such as bones of large fish or other vertebrates). For other protocetids, a diet of smaller fish has been suggested (O'Leary and Uhen 1999).

Protocetids are usually found in near-shore marine deposits, often associated with carbonate platforms such as reefs (Williams 1998). In India and Pakistan, protocetids are found in the same areas as remingtonocetids (Gingerich et al. 1997; Bajpai and Thewissen 1998; Gingerich et al. 1995a, b; Fig. 22). The former species were larger and had larger eyes (Fig. 23), suggesting that they hunted different prey. While Indian localities suggestive of a muddy lagoon with abundant plant growth (Bajpai et al. 2006) abound in some remingtonocetids, protocetids are usually found in clearer water deposits that are more exposed to wave action.

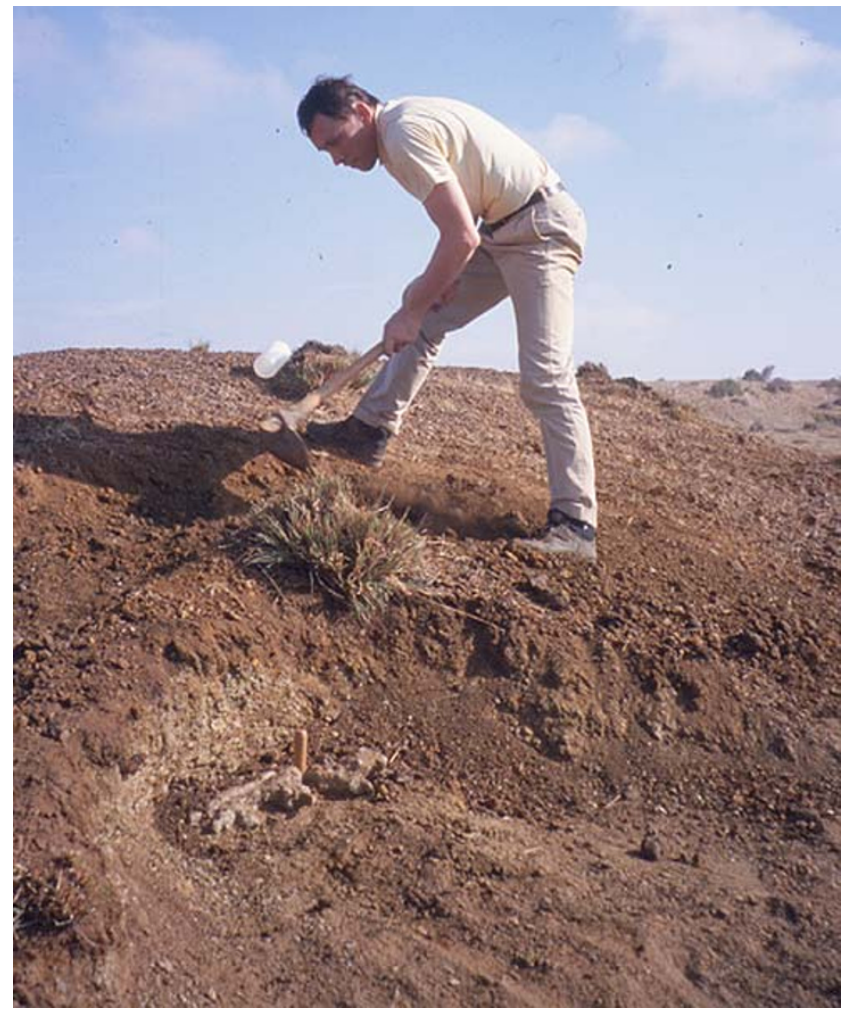

Fig. 22 Excavation of a fossil, left foreground, in Gujarat, India. Both remingtonocetids and protocetids are found in the same areas of India

\section{Basilosauridae: the First Fully Aquatic Cetaceans}

In the late middle Eocene, around 41 million years ago, a new kind of cetacean emerged, the first one that resembles modern cetaceans: Basilosauridae (Uhen 1998). Basilosaurids have a nasal opening that has shifted back far toward the eyes to

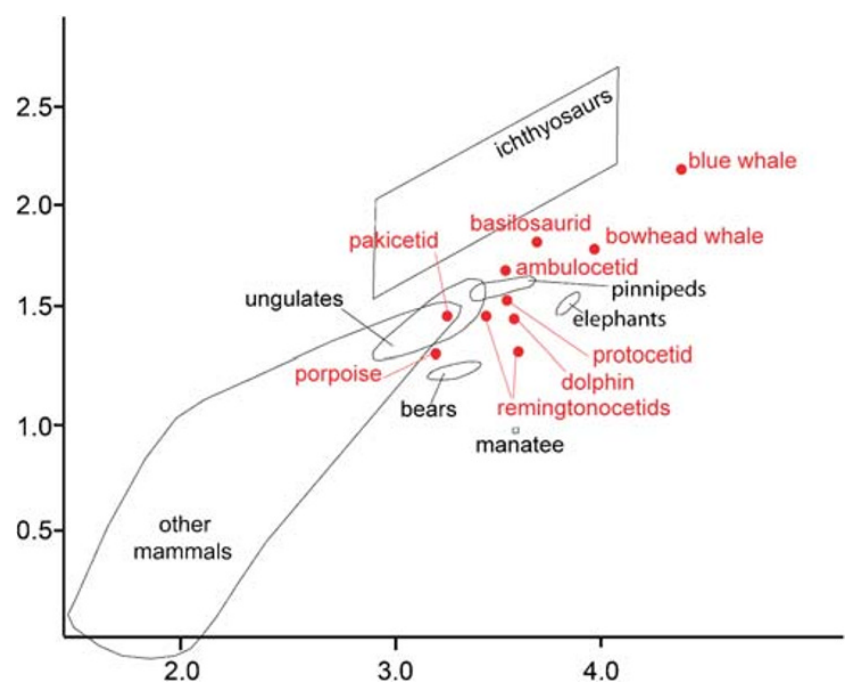

Fig. 23 Eye size in cetaceans and extinct marine reptiles (ichthyosaurs; modified from Thewissen and Nummela (2008), (C) University of California Press) 
form a blowhole and have flippers for forelimbs, a fluke at the end of the tail, and tiny hind limbs, too tiny to support the body weight on land. In all these features, basilosaurids are more similar to modern cetaceans than to protocetids, and it is likely that they did not leave the oceans and were the first obligate cetaceans (Kellogg 1936; Uhen 2004).

There are approximately seven genera of basilosaurid cetaceans, but basically they can be divided into two body types. The first occurs in the genus Basilosaurus which had a snake-like body with a maximum length of approximately $17 \mathrm{~m}$ long. Basilosaurus may have swum by sinuous movements of its entire body (Buchholtz 1998). The second body type among basilosaurids is shorter, as short as $4 \mathrm{~m}$. These basilosaurids, called dorudontines (Uhen 1998), had dolphin-shaped bodies and swam by up-and-down motions of their tail fluke. Basilosaurids are known from all the New World and the Old World and probably lived in all seas between 41 and 35 million years ago. The great length of the vertebral column of basilosaurids can be attributed to the increase in the number of lumbar vertebrae in the taxon but also by the increase in length of each individual vertebra.

Similar to earlier archaeocetes and unlike most later cetaceans, basilosaurids retained a heterodont dentition, with clear morphological differences between incisors, canines, premolars, and molars (Uhen 2004). This is unlike modern (odontocete) cetaceans in which the teeth along the tooth row are all very similar (a condition called homodonty). Unlike earlier archaeocetes, which all had 11 teeth per half jaw (44 teeth in all), basilosaurids had lost one tooth in each upper jaw, bringing their total number to 42 . Their molars differed greatly from those of protocetids and ambulocetids, there not being a central depression surrounded by three cusps in the upper molars (O'Leary and Uhen 1999). As such, these teeth are not suitable for crushing food.

In the forelimb, basilosaurids resemble modern cetaceans, in that their elbow joint is not separately mobile and their hand webbed with individual digits not recognizable (Uhen
2004). Basilosaurids are like most mammals in that there are only three phalanges per finger, whereas in modern cetaceans this number is commonly increased.

The hind limbs of basilosaurids retain the bones present in earlier whales and indeed land mammals: the femur, tibia, fibula, tarsals, metatarsals, and phalanges (Gingerich et al. 1990). However, the hind limbs are greatly reduced in size and the pelvis is not attached to the vertebral column, making the hind limbs unsuitable to support the body weight of these whales. There are no external hind limbs in normal modern cetaceans, although, very rarely, an anomalous individual with such limbs is born (Fig. 24). Internally, there are pelvic or hind limb remnants in all species, which provide origin for the muscles to the genitals. In some species, pelvis, femur, and tibia are present (Figs. 25 and 26). Given that the basilosaurid hind limb preserves even bones of the foot, it is reasonable to assume that some of it projected from the basilosaurid body as Gingerich et al. (1990) proposed.

\section{Odontoceti and Mysticeti: Modern Cetaceans}

Around 34 million years ago, the first representatives of the modern groups of whales, odontocetes and mysticetes are found. It is now generally assumed that odontocetes and mysticetes (together called Neoceti) arose from a common Eocene cetacean ancestor and are thus monophyletic. The most important innovation of the odontocete body plan is the acquisition of echolocation: These animals produce sounds that are reflected from objects that surround them, and these reflections enable them to image their surroundings. Mysticetes acquired a novel feeding mechanism: they filter feed for bulk prey (e.g., krill), using strainers in their mouth, the baleen plates. Although echolocation and filter feeding are important evolutionary themes of odontocetes and mysticetes, respectively, both of these suborders are diverse, feeding on different prey and using different hunting techniques.
Fig. 24 Hind flippers present in a single anomalous dolphin housed at the Taiji Whale Museum

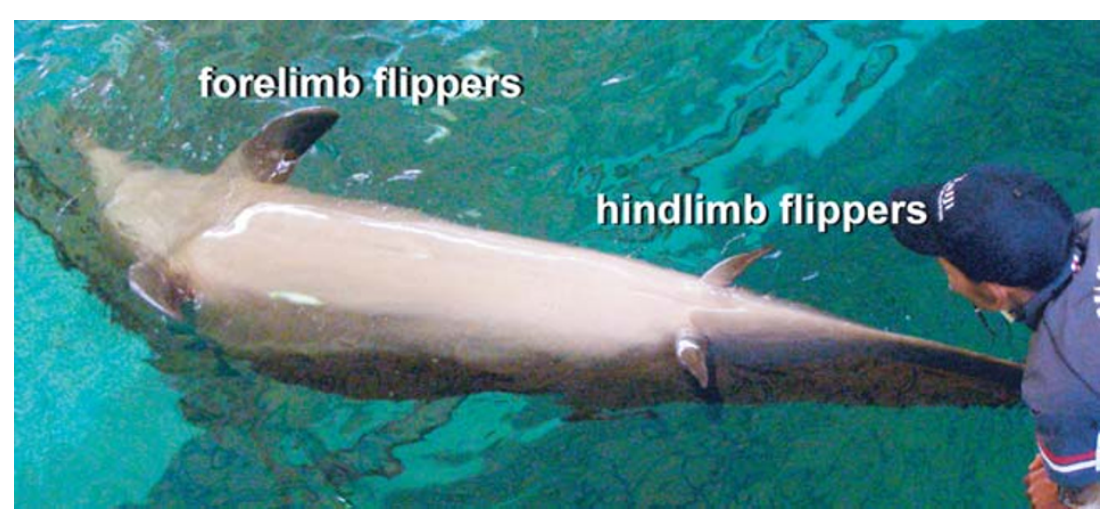


Fig. 25 Diagram showing the approximate location of the pelvis and hind limb of a male bowhead whale (Balaena mysticetus) in $(A)$ lateral view and $(B)$ dorsal view. $(C)$ The pelvis is attached to the femur with a synovial joint, and a small cartilaginous tibia is also present (B. mysticetus, 06B4; Lucas 1900; Struthers 1893). $(D)$ Pelvis and femur of the juvenile male specimen figured in $C .(E)$ Another pelvis and femur from an adult specimen (B. mysticetus, 98B5) for comparison. Specimens courtesy of John Craighead George and the Barrow Whaling Captains Association

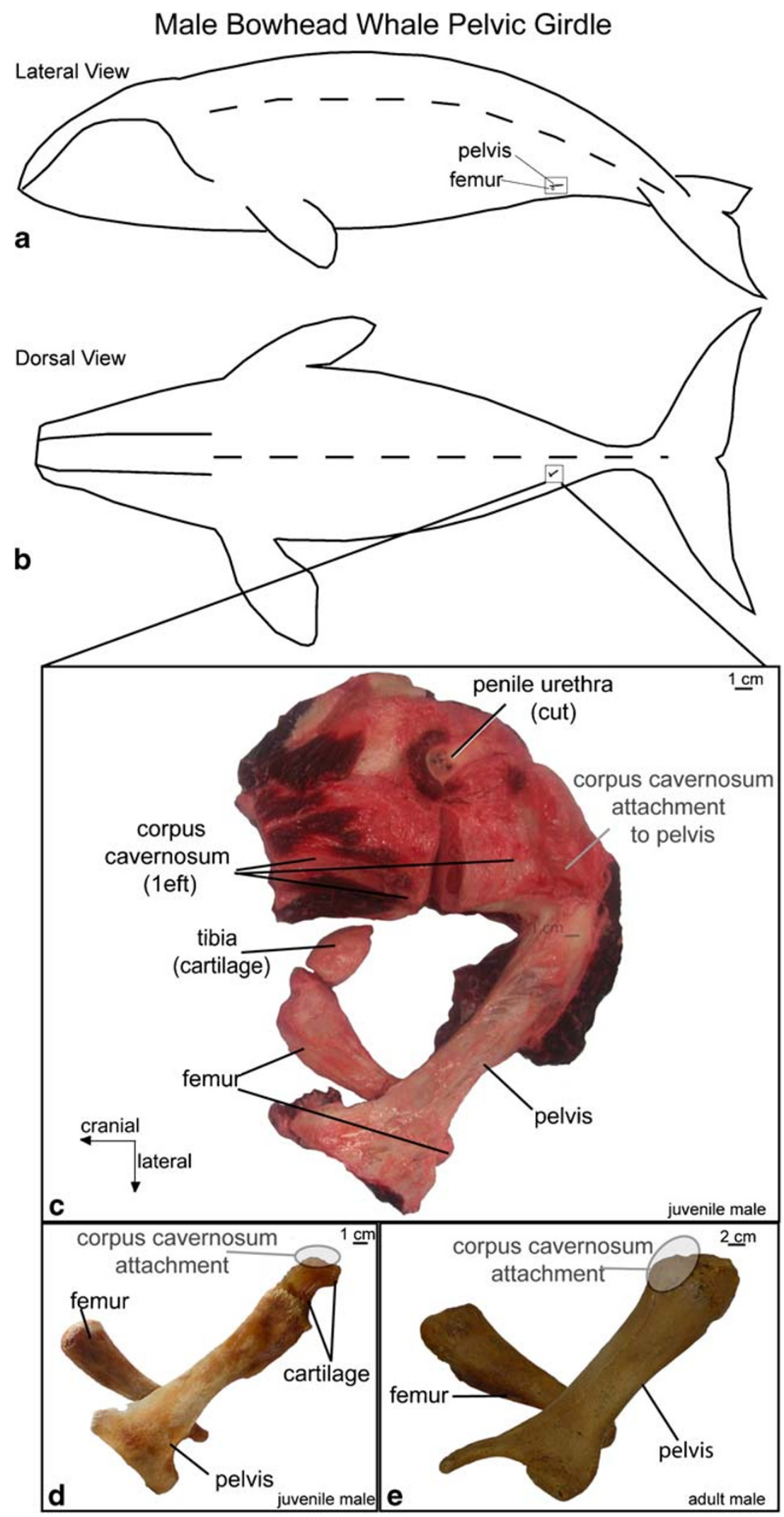


Fig. 26 Diagram showing changes in the pelvis of Indohyus (RR 256) and cetaceans. Pakicetids are the earliest cetaceans and had a pelvis that was similar to most terrestrial mammals (composite of H-GSP 30395, 30213). The pelvis of Ambulocetus was large and weight bearing (H-GSP 18507), but, in Basilosaurus (US National Museum 12261), the pelvis was no longer attached to the vertebrae and the ilium was very reduced. In modern bowhead whales (pictured here is the pelvis of an adult male, B. mysticetus,

98B5), the acetabulum and obturator foramen are lost and the ilium is reduced

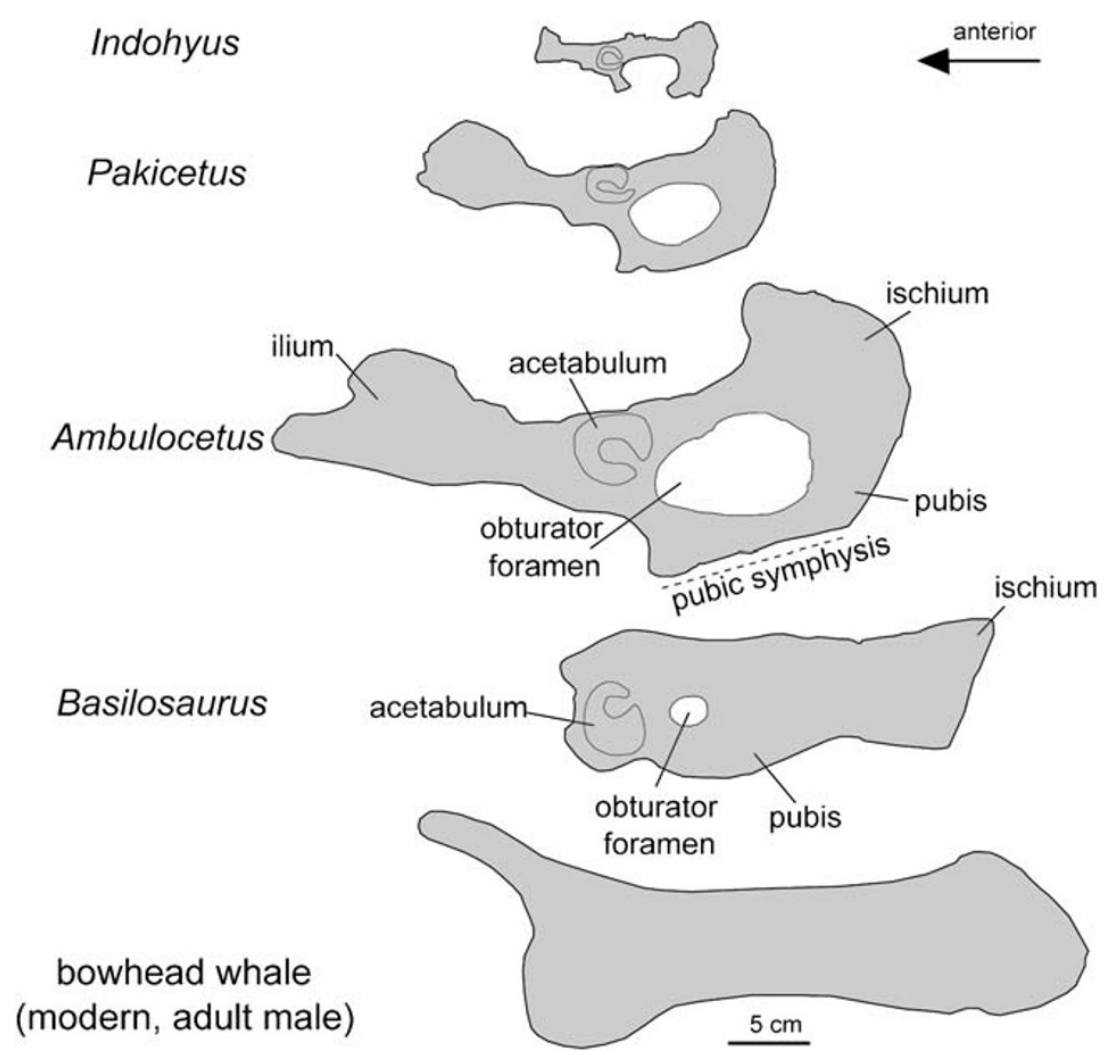

Odontocetes and mysticetes conquered nearly all of the oceans: they include coastal and off-shore forms, arctic and tropical waters, shallow water, deep sea, and riverine forms. Good introductions to the evolutionary history of odontocetes and mysticetes have been published (Fordyce and Muizon 2001; Bianucci and Landini 2007).

\section{Conclusion}

In the past two decades, the origin of whales has gone from being based on barely any fossils to one of the bestdocumented examples of macroevolution (Fig. 27). In spite of this record, there is room for much more research. For
Fig. 27 The changing cetacean body plan during the first ten million years of cetacean evolution. Pictured are five families of archaeocetes, the oldest being the pakicetids, while the youngest are the basilosaurids (modified from Thewissen et al. (2002), (C) Annual Reviews)

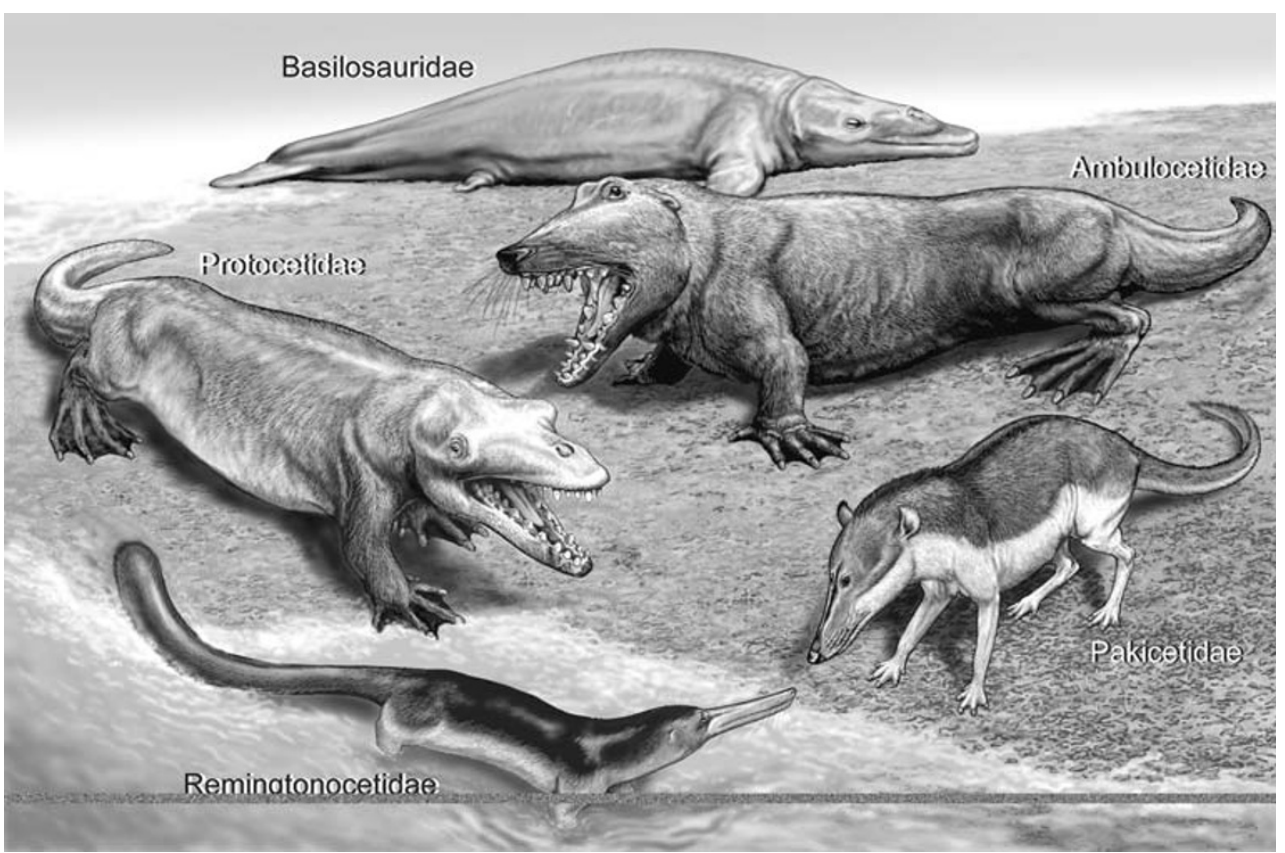


example, protocetids are diverse and many of them are poorly known, and the evolution of some organ systems (e.g., vision) is poorly understood (Thewissen and Nummela 2008).

In spite of our advances in understanding of the pattern of cetacean origins, it remains unclear which process caused this pattern: Why did cetaceans enter the oceans? The availability of rich new food sources has been proposed as a reason for the cetacean entry into the water, but this is unlikely, given that cetacean ancestors already lived in very shallow freshwater. The new find of aquatic behaviors in raoellids suggests that these animals used the water as a refuge against danger. Raoellid teeth are very different from those of early cetaceans, suggesting that a dietary shift took place after the habitat change and may have been critical in the early diversification of cetaceans but not in their entry into the water. On the other hand, it is not clear what raoellids ate, and neither raoellid nor early cetacean dentitions have good modern analogs. It has been suggested that early cetaceans ate fish (O'Leary and Uhen 1999).

The rich fossil record that has emerged can now be used to enrich other subfields of evolutionary science, including developmental biology, comparative anatomy, and molecular systematics. We hope that a detailed understanding of evolutionary patterns will allow us to determine the processes that drove cetacean evolution.

Acknowledgements We thank the Geological Survey of Pakistan for collaborating in collecting and studying Pakistani fossils and for logistic support, and Dr. S. Taseer Hussain for his leadership of the Howard University-Geological Survey of Pakistan project. We thank Ajay Thakore and the Gujarat Mining Development Corporation for assistance with fieldwork in Gujarat, and Mr. Bhatti of Bhuj for help with logistics. We thank the Alaska Eskimo Whaling Commission and the Barrow Whaling Captains Association for access to specimens and contributing to their scientific study. The Bowhead whale specimens were collected under NMFS marine mammal collection permit 8141899. We also thank the Department of Wildlife, North Slope Borough, and the Barrow Arctic Science Consortium for logistic support and assistance in the acquisition of specimens. This work was supported by grants from the Indian Department of Science and Technology (to Sunil Bajpai) and the US National Science Foundation (to J. G. M. Thewissen).

Open Access This article is distributed under the terms of the Creative Commons Attribution Noncommercial License which permits any noncommercial use, distribution, and reproduction in any medium, provided the original author(s) and source are credited.

\section{References}

Aslan A, Thewissen JGM. Preliminary evaluation of Kuldana paleosols and implications for interpreting vertebrate fossil assemblages, Kuldana Formation, Northern Pakistan. Palaeovert. 1997;25:261-77.

Bajpai SB, Thewissen JGM. Middle Eocene cetaceans from the Harudi and Subathu Formations of India. In: Thewissen JGM, editor. The emergence of whales: evolutionary patterns in the origin of Cetacea. 1st ed. New York: Plenum; 1998. p. 213-34.
Bajpai S, Thewissen JGM. A new, diminutive whale from Kachchh (Gujarat, India) and its implications for locomotor evolution of cetaceans. Curr Sci (New Delhi). 2000;79:1478-82.

Bajpai SB, Thewissen JGM, Kapur VV, Tiwari BN, Sahni S. Eocene and Oligocene sirenians (Mammalia) from Kachchh, India. J Vert Pal. 2006;26:400-10.

Bianucci G, Landini W. Fossil history. In: Miller DE, editor. Reproductive biology and phylogeny of Cetacea. 1st ed. Enfield: Science Publ; 2007. p. 35-94.

Buchholtz EA. Implications of vertebral morphology for locomotor evolution in early Cetacea. In: Thewissen JGM, editor. The emergence of whales: evolutionary patterns in the origin of Cetacea. 1st ed. New York: Plenum; 1998. p. 325-52.

Clementz MT, Goswami A, Gingerich PD, Koch PL. Isotopic records from early whales and sea cows: contrasting patterns of ecological transition. J Vert Pal. 2006;26:355-70.

Fish FE. Transitions from drag-based to lift-based propulsion in mammalian swimming. Am Zool. 1996;36:628-41.

Fordyce E, Muizon Cd. Evolutionary history of cetaceans: a review. In: Mazin J-M, Buffrénil VD, editors. Secondary adaptation of tetrapods to life in water. 1st ed. Munich: Verlag Friedrich Pfeil; 2001. p. 169233.

Gatesy J, O'Leary MA. Deciphering whale origins with molecules and fossils. Tr Ecol Evol. 2001;16:562-70.

Geisler JH, Uhen MD. Morphological support for a close relationship between hippos and whales. J Vert Pal. 2003;23:991-6.

Geisler JH, Saunders AE, Luo Z-X. A new protocetid whale (Cetacea, Archaeoceti) from the late middle Eocene of South Carolina. Am Mus Nov. 2005;3480:1-65.

Geisler JH, Theodor JM, Uhen MD, Foss SE. Phylogenetic relationships of cetaceans to terrestrial artiodactyls. In: Prothero DR, Foss SE, editors. The evolution of artiodactyls. 1st ed. Baltimore: Johns Hopkins Univ Pr; 2007. p. 19-31.

Gingerich PD, Smith BH, Simons EL. Hind limbs of Basilosaurus isis: evidence of feet in whales. Science. 1990;229:154-7.

Gingerich PD, Raza SM, Arif M, Anwar M, Zhou X. New whale from the Eocene of Pakistan and the origin of cetacean swimming. Nature. 1994;368:844-7.

Gingerich PD, Arif M, Bhatti MA, Raza HA, Raza M. Protosiren and Babiacetus (Mammalia, Sirenia and Cetacea) from the middle Eocene Drazinda Formation, Sulaiman Range, Punjab (Pakistan). Contr Mus Pal Univ Michigan. 1995a;29:331-57.

Gingerich PD, Arif M, Clyde WC. New archaeocetes (Mammalia, Cetacea) from the middle Eocene Domanda Formation of the Sulaiman Range, Punjab, Pakistan. Contr Mus Pal Univ Michigan. 1995b;29:291-330.

Gingerich PD, Arif M, Bhatti MA, Anwar M, Sanders WJ. Basilosaurus drazindai and Basiloterus hussaini, new Archaeoceti (Mammalia, Cetacea) from the middle Eocene Drazinda Formation, with a revised interpretation of ages of whale-bearing strata in the Khirthar Group of the Sulaiman Range, Punjab (Pakistan). Contr Mus Pal Univ Michigan. 1997;30:55-81.

Gingerich PD, Ul-Haq M, Khan IH, Zalmout I. Eocene stratigraphy and archaeocete whales (Mammalia, Cetacea) of Drug Lahar in the eastern Sulaiman Range, Balochistan (Pakistan). Contr Mus Pal Univ Michigan. 2001a;30:269-319.

Gingerich PD, Haq M, Zalmout IS, Khan IH, Malkani MS. Origin of whales from early artiodactyls: hands and feet of Eocene Protocetidae from Pakistan. Science. 2001b;293:2239-42.

Hulbert RC Jr. Postcranial osteology of the North American middle Eocene protocetid Georgiacetus. In: Thewissen JGM, editor. The emergence of whales: evolutionary patterns in the origin of Cetacea. 1st ed. New York: Plenum; 1998. p. 235-67.

Hulbert RC Jr, Petkewich RM, Bishop GA, Burky D, Aleshire DP. A new middle Eocene protocetid whale (Mammalia: Cetacea: Archaeoceti) and associated biota from Georgia. J Pal. 1998;72:905-25. 
Kellogg R. A review of the Archaeoceti. Carnegie Institute of Washington Publication, vol. 482. Washington: Carnegie Institute of Washington; 1936. p. 1-366.

Lucas FA. The pelvic girdle of zeuglodon, Basilosaurus cetoides (Owen), with notes on other portions of the skeleton. Proc US Natl Mus. 1900;23:327-31.

Madar SI. Structural adaptations of early archaeocete long bones. In: Thewissen JGM, editor. The emergence of whales, evolutionary patterns in the origin of Cetacea. 1st ed. New York: Plenum; 1998. p. 353-78.

Madar SI. The postcranial skeleton of pakicetid cetaceans. J Pal. 2007;81:176-200.

Madar SI, Thewissen JGM, Hussain ST. Additional holotype remains of Ambulocetus natans (Cetacea, Ambulocetidae), and their implications for locomotion in early whales. J Vert Pal. 2002;22:405-22.

Nikaido M, Rooney AP, Okada N. Phylogenetic relationships among cetartiodactyls based on insertions of short and long interspersed elements: hippopotamuses are the closest extant relatives of whales. Proc Natl Acad Sci USA. 1999;96:10261-6.

Nummela S, Thewissen JGM, Bajpai S, Hussain ST, Kumar K. Eocene evolution of whale hearing. Nature. 2004;430:776-8.

Nummela S, Hussain ST, Thewissen JGM. Cranial anatomy of Pakicetidae (Cetacea, Mammalia). J Vert Pal. 2006;26:746-59.

Nummela S, Thewissen JGM, Bajpai S, Hussain ST, Kumar K. Sound transmission in archaic and modern whales: anatomical adaptations for underwater hearing. Anat Rec. 2007;290:716-33.

O'Leary MA, Uhen MD. The time of origin of whales and the role of behavioral changes in the terrestrial-aquatic transition. Paleobiology. 1999;25:534-56.

Roe LJ, Thewissen JGM, Quade J, O'Neil JR, Bajpai S, Sahni A, et al. Isotopic approaches to understanding the terrestrial to marine transition of the earliest cetaceans. In: Thewissen JGM, editor. The emergence of whales, evolutionary patterns in the origin of Cetacea. 1st ed. New York: Plenum; 1998. p. 399-421.

Spoor F, Thewissen JGM. Comparative and functional anatomy of balance in aquatic mammals. In: Thewissen JGM, Nummela S, editors. Senses on the threshold: adaptations in secondarily aquatic vertebrates. Berkeley: Univ Calif Press; 2008. p. 257-86.

Spoor F, Bajpai S, Hussain ST, Kumar K, Thewissen JGM. Vestibular evidence for the evolution of aquatic behaviour in early cetaceans. Nature. 2002;417:163-6.
Struthers MD. On the rudimentary hind limb of the great fin-whale (Balaenoptera musculus) in comparison with those of the humpback whale and the Greenland Right Whale. J Anat Physiol. 1893;27:291-335.

Thewissen JGM, Bajpai S. Dental morphology of the Remingtonocetidae (Cetacea, Mammalia). J Pal. 2001a;75:463-5.

Thewissen JGM, Bajpai S. Whale origins as poster child for macroevolution. BioSci. 2001b;5:1037-49.

Thewissen JGM, Fish FE. Locomotor evolution in the earliest cetaceans: functional model, modern analogues, and paleontological evidence. Paleobiology. 1997;23:482-90.

Thewissen JGM, Williams EM. The early evolution of Cetacea (whales, dolphins, and porpoises). Ann Rev Ecol Syst. 2002;33:73-90.

Thewissen JGM, Nummela S. Sensory evolution in aquatic tetrapods: toward and integrative approach. In: Thewissen JGM, Nummela S, editors. Sensory biology on the threshold: adaptations in secondarily aquatic vertebrates. Berkeley: Univ Calif Press; 2008. p. 333-330.

Thewissen JGM, Hussain ST, Arif M. Fossil evidence for the origin of aquatic locomotion in archaeocete whales. Science. 1994;263:210-2.

Thewissen JGM, Madar SI, Hussain ST. Ambulocetus natans, an Eocene cetacean (Mammalia) from Pakistan. Cour Forsch Inst Senckenberg. 1996;190:1-86.

Thewissen JGM, Williams EM, Hussain ST. Eocene mammal faunas from northern Indo-Pakistan. J Vert Pal. 2001;21:347-66.

Thewissen JGM, Cohn MJ, Stevens LS, Bajpai S, Heyning J, Horton WE Jr. Developmental basis for hind limb loss in dolphins and the origin of the cetacean body plan. Proc Natl Acad Sci USA. 2006;103:8414-8.

Thewissen JGM, Cooper LN, Clementz MT, Bajpai S, Tiwari BN. Whales originated from aquatic artiodactyls in the Eocene epoch of India. Nature. 2007;450:1190-5.

Uhen MD. Middle to late Eocene basilosaurines. In: Thewissen JGM, editor. The emergence of whales: evolutionary patterns in the origin of Cetacea. 1st ed. New York: Plenum; 1998. p. 29-61.

Uhen MD. Form, function, and anatomy of Dorudon atrox (Mammalia, Cetacea): an archaeocete from the middle to late Eocene of Egypt. Univ Michigan Pap Pal. 2004;34:1-222.

Williams EM. Synopsis of the earliest cetaceans: Pakicetidae, Ambulocetidae, Remingtonocetidae, and Protocetidae. In: Thewissen JGM, editor. The emergence of whales: evolutionary patterns in the origin of Cetacea. 1st ed. New York: Plenum; 1998. p. 1-28. 